\title{
Modeling the impact of floating oyster (Crassostrea virginica) aquaculture on sediment-water nutrient and oxygen fluxes
}

\author{
Jeremy M. Testa ${ }^{1, *}$, Damian C. Brady ${ }^{2}$, Jeffrey C. Cornwell ${ }^{3}$, Michael S. Owens ${ }^{3}$, \\ Lawrence P. Sanford ${ }^{3}$, Carter R. Newell ${ }^{4}$, Steven E. Suttles ${ }^{3}$, Roger I. E. Newell ${ }^{3}$ \\ ${ }^{1}$ Chesapeake Biological Laboratory, University of Maryland Center for Environmental Science, PO Box 38, Solomons, \\ MD 20688, USA \\ ${ }^{2}$ School of Marine Sciences, University of Maine, 193 Clark Cove Road, Walpole, ME 04573, USA \\ ${ }^{3}$ Horn Point Laboratory, University of Maryland Center for Environmental Science, 2020 Horns Point Road, Cambridge, \\ MD 20613, USA \\ ${ }^{4}$ Maine Shellfish R\&D, 7 Creek Lane, Damariscotta, ME 04543, USA
}

\begin{abstract}
Bivalve aquaculture relies on naturally occurring phytoplankton, zooplankton, and detritus as food sources, thereby avoiding external nutrient inputs that are commonly associated with finfish aquaculture. High filtration rates and concentrated bivalve biomass within aquaculture operations, however, result in intense biodeposition of particulate organic matter (POM) on surrounding sediments, with potential adverse environmental impacts. Estimating the net depositional flux is difficult in shallow waters due to methodological constraints and dynamic processes such as resuspension and advection. In this study, we combined sediment trap deployments with simulations from a mechanistic sediment flux model to estimate seasonal POM deposition, resuspension, and processing within sediments in the vicinity of an eastern oyster Crassostrea virginica farm in the Choptank River, Maryland, USA. The model is the stand-alone version of a 2-layer sediment flux model currently implemented within larger models for understanding ecosystem responses to nutrient management. Modeled sediment-water fluxes were compared to observed denitrification rates and nitrite + nitrate $\left(\mathrm{NO}_{2}{ }^{-}+\mathrm{NO}_{3}{ }^{-}\right)$, phosphate $\left(\mathrm{PO}_{4}{ }^{3-}\right)$ and dissolved $\mathrm{O}_{2}$ fluxes. Model-derived estimates of POM deposition, which represent POM incorporated and processed within the sediment, comprised a small fraction of the material collected in sediment traps. These results highlight the roles of biodeposit resuspension and transport in effectively removing oyster biodeposits away from this particular farm, resulting in a highly diminished local environmental impact. This study highlights the value of sediment models as a practical tool for computing integrated measures of nitrogen cycling as a function of seasonal dynamics in the vicinity of aquaculture operations.
\end{abstract}

KEY WORDS: Biogeochemistry $\cdot$ Nutrient cycling $\cdot$ Oyster $\cdot$ Modeling $\cdot$ Sediments $\cdot$ Biodeposition

\section{INTRODUCTION}

Molluscan aquaculture is thriving in many US coastal bays and estuaries (Newell 2004, Murray \& Hudson 2013) with a value of US $\$ 328$ million in 2013 representing a $75 \%$ growth rate since 2005 . On the US east coast, 315 farms grew US $\$ 68.3$ million worth of

${ }^{*}$ Corresponding author: jtesta@umces.edu eastern oysters and 278 farms grew US\$64.6 million worth of hard clams in 2013 (NASS 2014). Despite these successes, many suitable locations that can sustain bivalve aquaculture have yet to be utilized. There are several reasons for this slow development, but a major impediment is considerable opposition to the use of public waters for aquaculture due to poten-

(C) The authors 2015. Open Access under Creative Commons by Attribution Licence. Use, distribution and reproduction are unrestricted. Authors and original publication must be credited. 
tial adverse environmental consequences (Langan et al. 2006, NRC 2010). Such opposition is based largely on early finfish aquaculture operations in coastal waters where excess feed and fecal material resulted in over-enrichment of organic matter in underlying sediments and caused adverse effects on benthic communities. Although these practices have improved due to higher feed utilization, better placement of farms (Dudley et al. 2000), and fallowing of sites, public perception of aquaculture practices remains unfavorable. In distinct contrast, bivalve aquaculture farms do not result in the import of new nutrients to the system because bivalves feed solely on naturally available phytoplankton (i.e. no nutrients are added); however, these operations transfer nutrients from the water-column to sediments. Consequently, adverse effects of overenrichment of underlying sediments occur due to deposition of organic matter by bivalve biodeposits (Crawford et al. 2003, Mallet et al. 2006, Mitchell 2006, Cranford et al. 2009, Dumbauld et al. 2009, Forrest et al. 2009, McKindsey et al. 2011).

Bivalves filter large quantities of phytoplankton and detritus from the water column, and unincorporated particulate organic matter (POM) is then transferred as feces and pseudofecal rejecta (collectively termed biodeposits) to the sediment surface (Bayne \& Newell 1983, Newell \& Langdon 1996, Ward \& Shumway 2004, Cranford et al. 2011). Settling biodeposits can have a range of ecosystem effects, depending on the physical and chemical conditions present during and after the settling process. High seston deposition rates (including POM) are often associated with high rates of oxygen uptake and nutrient release by sediments (Mazouni et al. 1996, Souchu et al. 2001). However, if biodeposits settle on sediments that contain oxygen in the surficial layers, $\mathrm{NH}_{4}^{+}$ regenerated from organic matter is oxidized to $\mathrm{NO}_{2}{ }^{-}$ and $\mathrm{NO}_{3}{ }^{-}$during nitrification, some of which diffuses into anaerobic sediments, where it may be converted to $\mathrm{N}_{2}$ via denitrification as coupled nitrificationdenitrification (Henriksen \& Kemp 1988, Seitzinger 1988, Rysgaard et al. 1994). In cases where suspension-feeding bivalves cause localized over-enrichment of the surrounding sediment, the depletion of oxygen near the sediment-water interface (Newell 2004) allows sulfide accumulation and associated nitrification inhibition, allowing regenerated nitrogen to remain in the system as $\mathrm{NH}_{4}{ }^{+}$, potentially supporting further algal and microbial production locally (Kaspar et al. 1985, Asmus \& Asmus 1991, Giles et al. 2006). While nitrogen retention may be desirable in nutrient-poor systems, the opposite is true in eutrophic systems, and these adverse effects of bivalve aquaculture have most often been observed in locations with weak water currents that do not promote the distribution of the biodeposits over a wide area of the underlying sediments (Tenore et al. 1982, Kaspar et al. 1985, Mazouni et al. 1996, Barranguet 1997, Mazouni 2004, Holyoke 2008).

Numerical models are valuable tools for integrating field data and increasing the spatial and temporal scope of investigations into the processes associated with the impacts of shellfish aquaculture on sediments. Many types of models have been used to compute biodeposition associated with shellfish aquaculture (Grant et al. 2005, Weise et al. 2009), stock production (Gangnery et al. 2001, Duarte et al. 2003), carrying capacity (Byron et al. 2011), and ecosystem effects and linkages (Ren et al. 2012). From a biogeochemical perspective, numerical models can be used to quantify the spatial and temporal impacts of aquaculture-derived POM deposition on underlying sediments and how these impacts are related to farm size, culture intensity, and the physical environment of the aquaculture site. Such models are valuable not only for scientific studies of the aquaculture operations themselves, but are more often useful for assessments of production capacity and resource management, including water quality criteria assessment for aquaculture operations.

The purpose of this study was to develop sediment biogeochemical modeling infrastructure capable of predicting changes in nutrient and oxygen cycling in sediments associated with an oyster aquaculture operation in the Choptank River, Chesapeake Bay, USA. This process-based approach allows for the backcalculation of realistic patterns of biodeposition by allowing the model to account for non-linear dynamics in nutrient cycling associated with a variable aerobic layer. Model-data comparisons and calibration were then used to examine spatial and temporal variability in sediment biogeochemical processes near the oyster farm, which in turn allowed for the examination of aquaculture-associated POM transport at the site. The final objective was to use the model to develop a nitrogen budget and assess the susceptibility of the site to the impacts of concentrated biodeposition.

\section{MATERIALS AND METHODS}

\section{Site description}

Our study site is an oyster farm (Marinetics) located on the southern shore of the Choptank River in eastern Chesapeake Bay, MD (Fig. 1). The farm oper- 

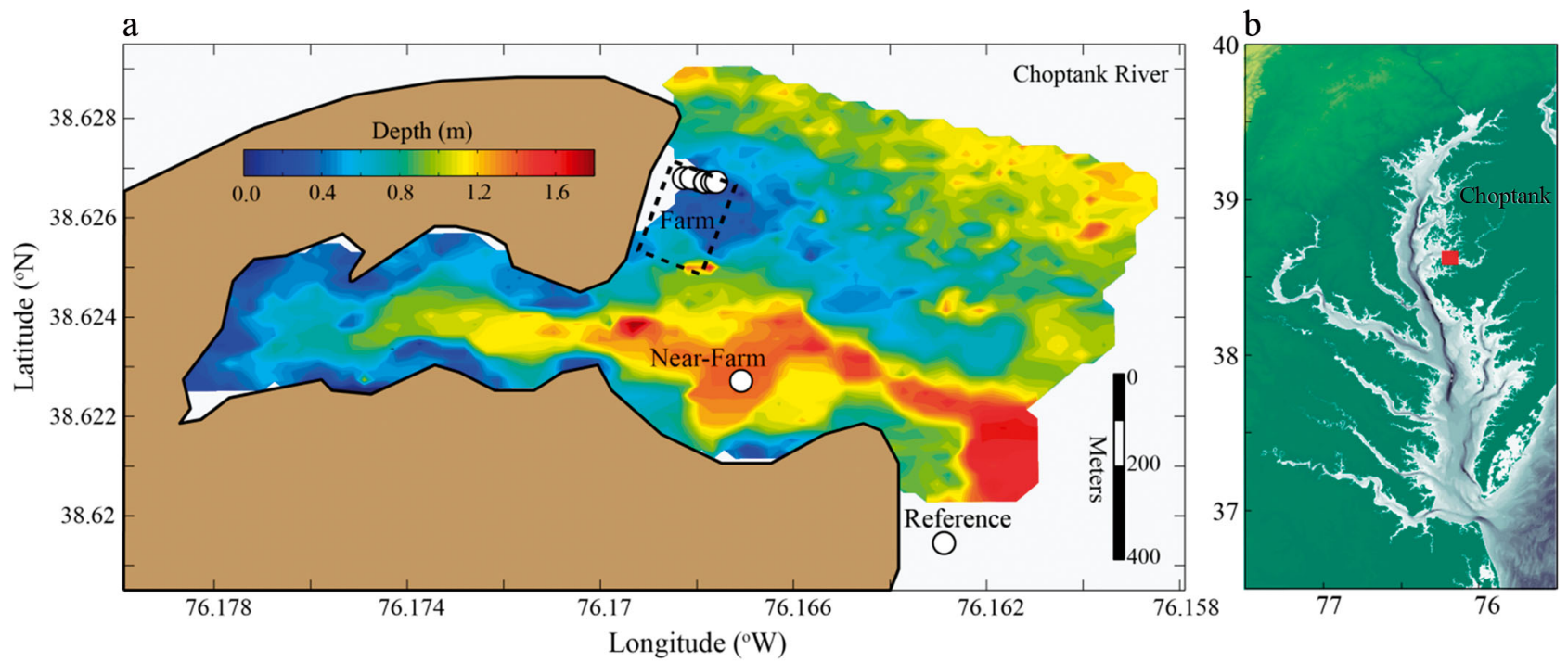

Fig. 1. (a) Map showing location of the farm, near-farm and reference sites in the Choptank River, (b) a tributary on the eastern shore of Chesapeake Bay. Contours represent local bathymetry relative to mean lower low water, and white circles represent locations of sediment trap deployments and sediment-water nutrient and oxygen exchange measurements

ates on a 4 -acre oyster lease stocked with up to 5000 floats $(0.75 \times 1.8 \mathrm{~m})$, each containing several thousand smaller $(0.5-3 \mathrm{~cm}$ shell height) or hundreds of larger (3-9 cm shell height) cultchless oysters. As oyster biomass in the floats increases during the growing season, oysters are removed from the floats, graded by size, and returned at lower densities. A sampling of some of the 2010 cohort (1.2 million oysters in 1020 trays) in 2011 averaged 663 oysters per tray (mean oyster shell length $=5.4 \mathrm{~cm}$ ), 422 per tray $(7.3 \mathrm{~cm})$, or 93 per tray $(8.8 \mathrm{~cm})$. Water temperature in the Choptank River ranged from $1-32^{\circ} \mathrm{C}$ over the course of the year, with May through October temperatures $>15^{\circ} \mathrm{C}$, and mean surface temperatures $>25^{\circ} \mathrm{C}$ from June to August when maximum growth and biodeposition was observed (Table 1). The local tidal range is $0.5 \mathrm{~m}$ and salinity ranged from 8 to 14 . The site is sheltered from the strongest northwest winds and has sediments ranging from sands to muds, with relatively shallow depths $(\sim 0.5-1.5 \mathrm{~m}$ at MLLW) (Fig. 1). Sediment trap deployments and sediment-water nutrient and oxygen flux measurements were carried out at 3 sites in and around the farm, including a site inside the oyster float matrix (farm site), a site $\sim 350 \mathrm{~m}$ south of the float matrix in about $2 \mathrm{~m}$ of water (near-farm site) and an adjacent reference location that is sufficiently distant $(\sim 800 \mathrm{~m}$ southeast) to be uninfluenced by oyster biodeposition, but otherwise similar to the farm site (reference site) (Table 1, Fig. 1). The near-farm site was chosen at a location that we hypothesized would tend to accumulate biodeposits, if dispersal from the farm was directed towards the land (southward) as op- posed to Riverward (northward). This is supported by the fact that sediments at this site are dominated by fine grained sediment (i.e. silt), which contrasts with the sand-dominated farm and reference sites (Table 1). The reference site was specifically chosen to have similar depth, bottom sediments, and geographical orientation to the farm site (Table 1, Fig. 1). A tidal model of the region, MIKE2D (J. Richardson pers.

Table 1. Characteristics of the farm $(n=4)$, near-farm $(n=2)$, and reference $(\mathrm{n}=1)$ sampling sites. Sediment $(0-1 \mathrm{~cm}$ depth) composition values correspond to medians for sampling sites measured in April 2011, where the overall median for the study area is $90.4 \%$ sand, $5.9 \%$ silt, and $3.7 \%$ clay $(n=25)$

\begin{tabular}{|c|c|c|c|}
\hline Depth (m) & $\begin{array}{c}\text { Farm } \\
1.1\end{array}$ & $\begin{array}{c}\text { Near-farm } \\
2.2\end{array}$ & $\begin{array}{c}\text { Reference } \\
1.4\end{array}$ \\
\hline \multicolumn{4}{|c|}{ Sediment organic carbon $(\%, 0-1 \mathrm{~cm})$} \\
\hline Apr & 0.21 & 0.57 & 0.18 \\
\hline Jun & 0.67 & 0.8 & 0.17 \\
\hline Sep & 0.4 & 0.8 & 0.12 \\
\hline \multicolumn{4}{|c|}{ Sediment organic nitrogen $(\%, 0-1 \mathrm{~cm})$} \\
\hline Apr & 0.03 & 0.07 & 0.03 \\
\hline Jun & 0.08 & 0.03 & 0.02 \\
\hline Sep & 0.06 & 0.10 & 0.02 \\
\hline \multicolumn{4}{|c|}{ Sediment composition } \\
\hline$\%$ Sand & 96.1 & 9.1 & 95.1 \\
\hline$\%$ Silt & 3.0 & 80.3 & 2.8 \\
\hline \% Clay & 0.9 & 10.7 & 2.1 \\
\hline \multicolumn{4}{|c|}{ Water temperature $\left({ }^{\circ} \mathrm{C}\right)$} \\
\hline Apr & 12.9 & 12.3 & 12.4 \\
\hline Jun & 24.8 & 24.8 & 25.9 \\
\hline Aug & 29.1 & 28.5 & 29.1 \\
\hline Sep & 23.0 & 23.1 & 23.3 \\
\hline
\end{tabular}


comm.) also shows very similar tidal currents (velocity and direction) at the farm and reference sites $(0.2$ $\mathrm{m} \mathrm{s}^{-1}$ alongshore at maximum ebb). The reference site allowed us to characterize seasonal processes associated with the cycling of naturally deposited and transported organic matter, but in the absence of significant biodeposition.

\section{Sediment trap deployments}

Estimates of POM deposition to the sediments at each study location and time were derived from sediment trap measurements. Sediment traps were deployed for approximately $24 \mathrm{~h}$ at 3 sites (farm, near-farm, reference) (Fig. 1) during 4 sampling cruises in 2011 (18 April, 6 June, 1 August, and 29 September). All deployments were during relatively calm conditions to avoid potential damage by large surface waves, and in water deep enough to ensure that the traps were never exposed or directly impacted by oyster floats during low tide. Traps (8 replicates at each site) were constructed from $5 \times 30.5 \mathrm{~cm}$ (internal diameter $\times$ height) PVC pipes that were supported vertically off the bed (off-bottom traps) in an additional piece of pipe $(7.6 \mathrm{~cm}$ diameter) embedded in cast concrete. The trap openings were approx. $30 \mathrm{~cm}$ above the sediment. For the 2 sampling periods in August and September, we also deployed 8 additional sediment traps (identical dimensions) that were suspended on monofilament line immediately underneath the oyster floats (under-float traps) to capture biodeposits as the material first settled from the floats.

Sediment traps deployed near the bottom in shallow tidal waters can be strongly influenced by bottom sediment resuspension (Ko et al. 2003). The sediment traps deployed at Marinetics oyster farm collected a combination of several types of organic matter, including background sedimentation, resuspension of both the ambient organic deposits and oyster biodeposits, and sedimentation of new oyster-derived feces and pseudo-feces from the farm. We used data from several trap deployments to estimate these contributions at each site. The off-bottom traps deployed at the reference site measured a combination of background (ambient) new sedimentation and resuspension unaffected by the oyster farm; these are referred to as the reference fluxes $\left(F_{\text {ref }}\right)$. The off-bottom trap deployed at the farm site measured a combination of background new sedimentation and resuspension, new biodeposition from the oyster floats, and resuspension of biodeposits (hereafter $F_{\text {tot }}$ ). The traps deployed directly beneath the oyster floats measured new biodeposition from the oyster floats $\left(F_{\mathrm{s}}\right) . F_{\mathrm{s}}$ was adjusted to account for the fact that the oyster floats only occupy a fraction, $r$, of the surface area of the farm site (Fig. 1), while the off-bottom traps represent an average of the whole bottom area. Over-flight images of the farm were used to calculate an $r$ of 0.43 , dividing the area occupied by floats within a representative subregion of the farm by the total area of that subregion. Thus, the magnitude of the biodeposition source term per unit bottom area was estimated as $r F_{\mathrm{s}}$.

Using all 3 sediment trap types and, given the above assumptions, the resuspended biodeposit flux $\left(F_{\text {res }}\right)$ was calculated as:

$$
F_{\text {res }}=F_{\text {tot }}-F_{\text {ref }}-r F_{\mathrm{s}}
$$

This estimate was calculated directly for the August and September 2011 observations at the oyster farm, but not for the April and June 2011 observations since no oyster float traps were deployed during these months, and no direct measurements of $r F_{\mathrm{s}}$ were available. To obtain reasonable estimates, we assumed that $r F_{\mathrm{s}}$ was a fraction $(A)$ of the total biodeposit flux caught in the off-bottom traps:

$$
r F_{\mathrm{s}}=A\left(F_{\text {tot }}-F_{\text {ref }}\right)
$$

Eq. (2) is based on the idea that greater biodeposition will be accompanied by proportionally greater biodeposit resuspension. Eq. (2) is also the simplest possible function that approaches 0 as $F_{\text {tot }}$ approaches $F_{\text {ref }}$ (i.e. as the influence of oysters approaches 0 ). Using the data for August and September (Table 2),

Table 2. Carbon flux estimates $\left(\mathrm{mmol} \mathrm{C} \mathrm{m}^{-2} \mathrm{~d}^{-1}\right)$ from the sediment traps and sediment flux model (SFM, monthly means). Italicized numbers represent estimates based on the average value of Ratio $A$ (fraction of new biodeposition captured in sediment traps) observed in August and September. SFM estimates are the deposition rates of particulate organic carbon, computed using the SFM in comparison to the farm site estimates from under-float and off-bottom traps (see 'Materials and methods: sediment trap deployments')

\begin{tabular}{|lrrrr|}
\hline & Apr & Jun & Aug & Sep \\
\hline Reference site off-bottom $\left(F_{\text {ref }}\right)$ & 280.24 & 661.68 & 613.86 & 237.96 \\
Farm site off-bottom $\left(F_{\text {tot }}\right)$ & 493.36 & 3095.04 & 2322.02 & 639.16 \\
Ratio $A$ & 0.67 & 0.67 & 0.57 & 0.78 \\
Farm site under-float $\left(r F_{\mathrm{s}}\right)$ & 143.16 & 1634.64 & 967.54 & 311.78 \\
Resuspended biodeposit $\left(F_{\text {res }}\right)$ & 69.96 & 798.72 & 740.62 & 89.42 \\
SFM estimate & 32.40 & 185.78 & 57.20 & 37.76 \\
\hline
\end{tabular}


when all 3 trap types were deployed, resulted in estimates of $A=0.57$ for August and $A=0.76$ for September. We adopted the average value of $A=0.67$ to estimate the biodeposit source term for April and June using Eq. (2) (Table 2). Finally, we estimated resuspended biodeposit fluxes using Eq. (1), with the results also listed in Table 2.

We also derived estimates of net POM deposition to sediments using a sediment flux model (SFM). This scheme estimates the annual POM deposition, which is the primary input to the biogeochemical model, so that the modeled sediment-water $\mathrm{NH}_{4}{ }^{+}$fluxes best fit the observed $\mathrm{NH}_{4}{ }^{+}$fluxes (Di Toro 2001). Because such a method ignores the year-to-year carryover of POM, adjusting the annual POM deposition to fit $\mathrm{NH}_{4}{ }^{+}$flux over a number of years is a complex estimation problem since every year affects each subsequent year in proportion to the store of organic material that did not undergo diagenesis (Brady et al. 2013). A Hooke-Jeeves pattern search algorithm was utilized to minimize the root mean square error (RMSE) between modeled and observed $\mathrm{NH}_{4}{ }^{+}$flux (Hooke \& Jeeves 1961, Brady et al. 2013). The algorithm minimizes a cost function; in this application the RMSE in the predicted $\mathrm{NH}_{4}{ }^{+}$flux is minimized by varying yearly average depositional fluxes. The pattern search starts with an initial estimate of the POM depositional flux, which in this case is a constant yearly organic matter depositional flux of $35 \mathrm{mmol} \mathrm{C}$ $\mathrm{m}^{-2} \mathrm{~d}^{-1}$, a reasonable estimate based on literaturederived values for similar sites in Chesapeake Bay, USA (Roden et al. 1995, Kemp et al. 1999, Hagy et al. 2005). This was followed by exploratory moves $( \pm 30 \%)$, changing the POM depositional flux for the first year, recording the direction that reduces the cost function (i.e. $\mathrm{NH}_{4}{ }^{+}$flux RMSE for the first year). This process is repeated for each year and the direction of change $( \pm 30 \%$ POM depositional flux $)$ that reduces the error is retained for each year. These directions of change that reduce the RMSE for each year of the pattern search are repeated until the RMSE no longer decreases. The individual year-byyear search is then repeated and a new pattern is established and repeatedly applied. If it is not possible to find a new pattern, that indicates a local minimum has been found. At this time, the size of the exploratory moves is reduced from \pm 30 to $\pm 10 \%$ in $10 \%$ intervals and finally $\pm 5 \%$ to converge to a final solution. The only constraint on depositional flux was a minimum of $8.3 \mathrm{mmol} \mathrm{C} \mathrm{m}^{-2} \mathrm{~d}^{-1}$, $10 \%$ below the lowest depositional flux measured in Chesapeake Bay (Kemp et al. 1999, Hagy et al. 2005).

\section{Sediment-water nutrient and oxygen fluxes}

Sediment-water fluxes of $\mathrm{NH}_{4}{ }^{+}, \mathrm{NO}_{2}{ }^{-}+\mathrm{NO}_{3}{ }^{-}, \mathrm{N}_{2}$, $\mathrm{PO}_{4}{ }^{3-}$, and $\mathrm{O}_{2}$ were estimated from temporal changes in constituents during 4 sets of core incubations. Sediments were collected and core incubations were performed on 10 April, 6 June, 1 August, and 26 September in 2011. Acrylic cores that were $7 \mathrm{~cm}$ (inner diameter) and $30 \mathrm{~cm}$ tall were collected by pole coring (Gao et al. 2014) at the 3 study sites (Fig. 1). The methods for core incubation are described in detail in Cornwell et al. (2014). Briefly, triplicate cores from each site that had aerobic overlying water conditions were bubbled with air overnight while submersed in a temperature controlled environmental chamber. Core tubes were sealed by acrylic lids with suspended magnetic stirrers attached and time series of solute $\left(\mathrm{NH}_{4}{ }^{+}, \mathrm{NO}_{\mathrm{x}}{ }^{-}, \mathrm{PO}_{4}{ }^{3-}\right)$ and gas $\left(\mathrm{O}_{2}, \mathrm{~N}_{2}, \mathrm{Ar}\right)$ concentrations were determined within the cores over the incubation period. Gas concentrations were measured from high precision $\mathrm{N}_{2}$ : $\mathrm{Ar}$ or $\mathrm{O}_{2}$ : Ar ratios using membrane inlet mass spectrometry (Kana et al. 1994). Cores were incubated in the dark for 4 time points and then under illumination at ambient irradiances for an additional 3 time points. While the fluxes of $\mathrm{N}_{2}$ are referred to as denitrification, they are actually the summation of all gaseous $\mathrm{N}$ transformation processes and may include processes such as anammox (Rich et al. 2008) or $\mathrm{N}$ fixation associated with sulfate reduction (Bertics et al. 2013); fluxes of $\mathrm{N}_{2} \mathrm{O}$ were not measured.

Data for overlying water-column nutrient and $\mathrm{O}_{2}$ concentrations nearest the sediment-water interface in Chesapeake Bay, which are required boundary conditions for the stand-alone SFM simulations, were retrieved from the Chesapeake Bay Program (CBP) Water Quality database (www.chesapeakebay.net/ data_waterquality.aspx) for a nearby site in the Choptank River (Stn ET5.2; 38.5807 N, 76.0587 W). Measurements of bottom water salinity, dissolved $\mathrm{O}_{2}$, $\mathrm{NH}_{4}{ }^{+}, \mathrm{NO}_{3}{ }^{-}$, and $\mathrm{PO}_{4}{ }^{3-}$ were also made as part of the sediment-water flux measurements and were augmented by CBP data by combining the time series and using piecewise cubic hermite interpolation (PCHIP) to derive daily overlying water-column values.

\section{Sediment biogeochemical modeling}

We applied a 2-layer sediment flux model (Di Toro 2001, Brady et al. 2013, Testa et al. 2013) to examine the biogeochemical response of the sediments given the POM depositional loading observed 


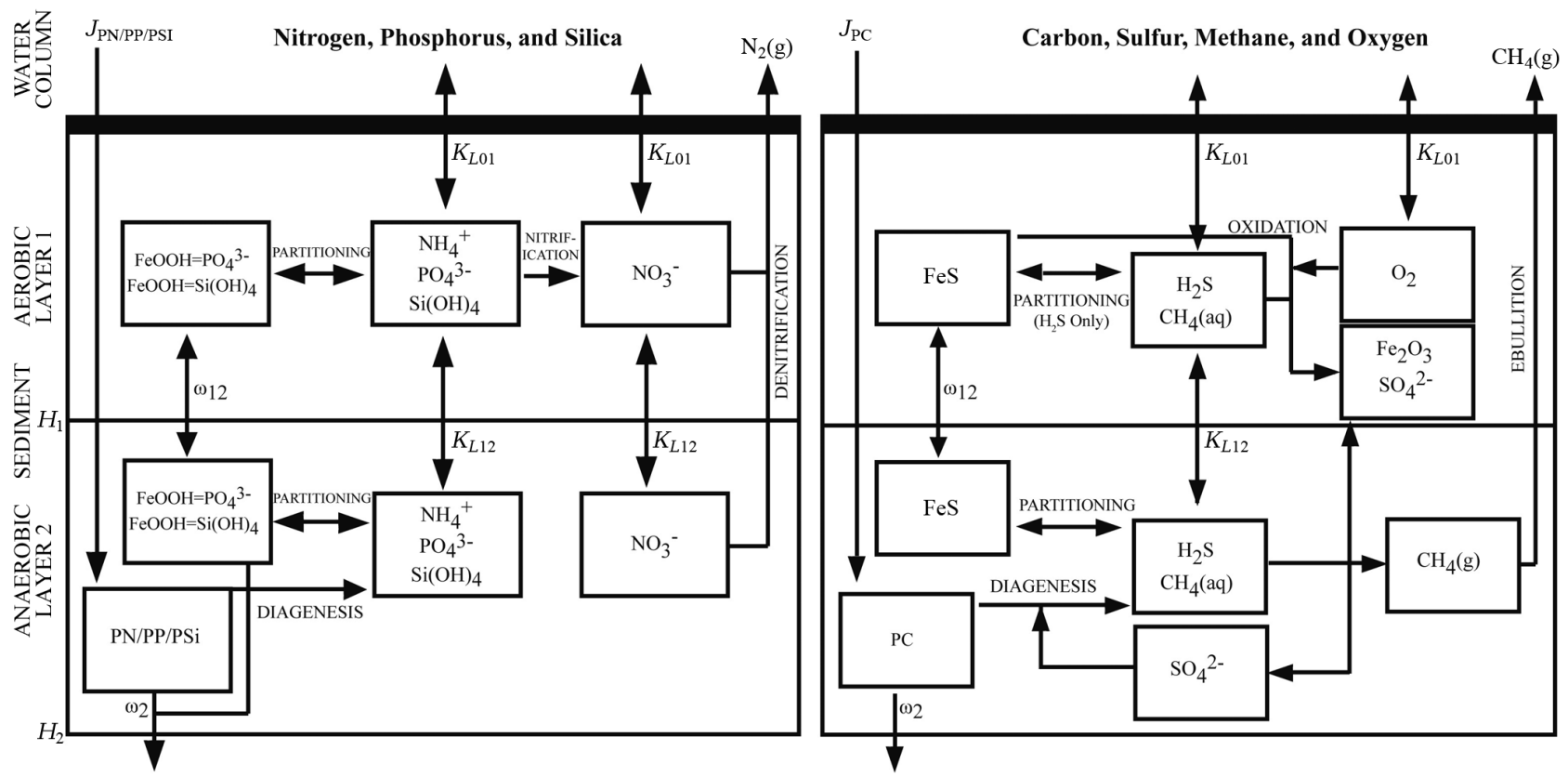

Fig. 2. Flow diagram illustrating the state variables, transport processes, and reactions in the sediment flux model, including those for nitrogen, phosphorus, and silica (left panel) and carbon, sulfur, methane, and oxygen (right panel). PN, PC, PSi, and $\mathrm{PP}$ are particulate nitrogen, carbon, silica, and phosphorus, respectively, and $\omega_{12}$ is the particle mixing rate between layers 1 and 2. Please refer to 'Materials and methods: sediment biochemical modeling' for parameter definitions

using sediment traps proximal to and distant from aquaculture facilities (Figs. 1 \& 2). SFM has accurately simulated sediment-water fluxes of $\mathrm{NH}_{4}{ }^{+}$, $\mathrm{NO}_{2}{ }^{-}$plus $\mathrm{NO}_{3}{ }^{-}, \mathrm{PO}_{4}{ }^{3-}$, and dissolved silica for diverse chemical and physical environments throughout Chesapeake Bay (Brady et al. 2013, Testa et al. 2013). The model structure for SFM involves 4 general processes: (1) the sediment receives depositional fluxes of POM $(\mathrm{C}, \mathrm{N})$, as well as biogenic and inorganic phosphorus and silica from the overlying water, (2) the decomposition of POM produces soluble intermediates that are quantified as diagenesis fluxes, (3) solutes react, transfer between solid and dissolved phases, are transported between the aerobic and anaerobic layers of the sediment, or are released as gases $\left(\mathrm{CH}_{4}, \mathrm{~N}_{2}\right)$, and (4) solutes are returned to the overlying water (Fig. 2). SFM numerically integrates mass-balance equations for chemical constituents in 2 functional layers: an aerobic layer near the sediment-water interface of variable depth $\left(H_{1}\right)$ and an anaerobic layer below that is equal to the total modeled sediment depth $(0.1 \mathrm{~m})$ minus the depth of $H_{1}$. The model includes an algorithm that continually updates the thickness of the aerobic layer, $H_{1}$. Values for $H_{1}$ are computed as the product of the diffusion coefficient $\left(D_{O_{2}} \mathrm{~m}^{2} \mathrm{~d}^{-1}\right)$ and the ratio of overlying water (layer 0 ) $\mathrm{O}_{2}$ concentration $\left(\mathrm{O}_{2}(0), \mathrm{mmol} \mathrm{m}^{-3}\right)$, to the sediment oxygen demand $\left(S O D, \mathrm{mmol} \mathrm{m}^{-2} \mathrm{~d}^{-1}\right)$ :

$$
H_{1}=D_{O_{2}} \frac{\left[O_{2}(0)\right]}{S O D}
$$

This relationship was perhaps first suggested by Grote (1934) — quoted by Hutchinson (1957) — and verified by measurements (Jorgensen \& Revsbech 1985, Cai \& Sayles 1996). The inverse of the second term on the right hand side of Eq. (3) is the surface mass transfer coefficient $\left(K_{L 01}, \mathrm{~m} \mathrm{~d}^{-1}\right)$ :

$$
K_{L 01}=\frac{D_{O_{2}}}{H_{1}}=\frac{S O D}{\left[O_{2}(0)\right]}
$$

The surface mass transfer coefficient controls solute exchange between the aerobic layer and the overlying water column (Fig. 2). The model can, therefore, use the same mass transfer coefficient for all the solutes since differences in the diffusion coefficients between solutes are subsumed in the kinetic parameters fitted to data (Di Toro 2001, Fennel et al. 2009). The model assumes that organic matter mineralization is achieved by denitrification, sulfate reduction, and methanogenesis, thus aerobic respiration is not explicitly modeled. The simulation time-step is $1 \mathrm{~h}$ and output is aggregated at $1 \mathrm{~d}$ intervals.

The key equations utilized to estimate particulate organic nitrogen deposition include the mass balance equations for $\mathrm{NH}_{4}{ }^{+}$in the aerobic and anaerobic layers in Eqs. (5 \& 6), respectively: 


$$
\begin{aligned}
& \frac{\mathrm{d}\left(H_{1}\left[N H_{4}^{+}(1)\right]\right)}{\mathrm{d} t}= \\
& \quad-k_{N H_{4}{ }^{+}, 1}\left[N H_{4}{ }^{+}(1)\right]-K_{L 01}\left\{\left[N H_{4}^{+}(1)-N H_{4}^{+}(0)\right]\right\}+ \\
& \quad K_{L 12}\left\{\left[N H_{4}^{+}(2)-N H_{4}^{+}(1)\right]\right\}+J_{N 1} \\
& \frac{\mathrm{d}\left\{H_{2}\left[N H_{4}^{+}(2)\right]\right\}}{\mathrm{d} t}=-K_{L 12}\left\{\left[N H_{4}{ }^{+}(2)-N H_{4}^{+}(1)\right]\right\}+J_{N 2}
\end{aligned}
$$

where $\mathrm{NH}_{4}{ }^{+}{ }_{(0)}, \mathrm{NH}_{4}{ }^{+}{ }_{(1)}$, and $\mathrm{NH}_{4}{ }^{+}{ }_{(2)}$ are the $\mathrm{NH}_{4}{ }^{+}$concentrations $\left(\mathrm{mmol} \mathrm{m}^{-3}\right)$ in the overlying water, aerobic, and anaerobic sediment layers, respectively. $K_{L 01}$ is the sediment-water mass transfer coefficient $\left(\mathrm{m} \mathrm{d}^{-1}\right), K_{L 12}$ is the mass transfer coefficient between the aerobic and anaerobic layer $\left(\mathrm{m} \mathrm{d}^{-1}\right), k_{\mathrm{NH}_{4}+1}$ is the nitrification reaction velocity $\left(\mathrm{m} \mathrm{d}^{-1}\right), H_{1}$ and $H_{2}$ are the depth of the aerobic and anaerobic layers, respectively (in meters), and $J_{N 1}$ and $J_{N 2}$ are the aerobic and anaerobic layer diagenesis rates, respectively ( $\mathrm{mmol} \mathrm{N} \mathrm{m}{ }^{-2} \mathrm{~d}^{-1}$ ).

The diagenesis of POM is modeled by partitioning the settling POM into 3 reactivity classes, termed the G model (Westrich \& Berner 1984). Each class represents a fixed portion of the organic material that reacts at a specific rate (Burdige 1991). For SFM, 3 G classes represent 3 levels of reactivity: $\mathrm{G}_{1}$ is rapidly reactive (20 d half-life, $65 \%$ of settling $P O M), G_{2}$ is more slowly reactive (1 $\mathrm{yr}$ half-life, $20 \%$ of settling POM), $\mathrm{G}_{3}$ (15\% of settling $\mathrm{POM}$ ) is non-reactive in this particular model (Brady et al. 2013). The diagenesis expression for carbon is as follows (similar equations govern diagenesis of particulate organic nitrogen and phosphorus):

$$
\begin{aligned}
& H_{2} \frac{\mathrm{dPOC}_{i}}{\mathrm{~d} t}= \\
& \quad-k_{\mathrm{POC}, i} \theta_{\mathrm{POC}, i}^{(T-20)} \mathrm{POC}_{i} H_{2}-\omega_{2} \mathrm{POC}_{i}+f_{\mathrm{POC}, i} J_{\mathrm{POC}}
\end{aligned}
$$

where $\mathrm{POC}_{i}$ is the $\mathrm{POC}$ concentration in reactivity class $i$ in the anaerobic layer $\left(\mathrm{mmol} \mathrm{m}^{-3}\right), k_{\mathrm{POC}, i}$ is the first order reaction rate coefficient $\left(\mathrm{d}^{-1}\right), \theta_{\mathrm{POC}, i}$ is the temperature coefficient, $T$ is water temperature $\left({ }^{\circ} \mathrm{C}\right), \omega_{2}$ is the burial velocity $\left(\mathrm{m} \mathrm{d}^{-1}\right), J_{\mathrm{POC}}$ is the depositional POC flux from the overlying water to the sediment $\left(\mathrm{mmol} \mathrm{m} \mathrm{m}^{-2} \mathrm{~d}^{-1}\right)$, and $f_{\mathrm{POC}, i}$ is the fraction of $J_{\mathrm{POC}}$ that is in the ith G class. The aerobic layer is not included, due to its small depth relative to the anaerobic layer: $H_{1} \approx 0.1 \mathrm{~cm}$, while $H_{2} \approx 10 \mathrm{~cm}$. Particulate nitrogen $\left(J_{\mathrm{PON}}\right)$, phosphorus $\left(J_{\mathrm{POP}}\right)$, and silica $\left(J_{\mathrm{PSi}}\right)$ deposition is based on Redfield stoichiometry. The details of the model structure and processes for phosphorus, nitrogen, silica, and sulfur (Fig. 2) are reported elsewhere (Di Toro 2001, Brady et al. 2013, Testa et al. 2013).

\section{Model setup, deposition time-series, and inclusion of oyster farm}

We ran multiple simulation scenarios at each of the 3 experimental sites ( 7 simulations in total) to quantify the realized and potential effects of background and oyster culture-derived biodeposition rates (including particulate biogenic $\mathrm{C}, \mathrm{N}$, and $\mathrm{P}$ ) on sediments. Specifically, these scenarios represent different assumptions regarding the amount of POM that is incorporated into the sediment: (1) all of the material collected in off-bottom sediment traps was incorporated into sediments, (2) a fraction of this material is resuspended, and resuspension fluxes are subtracted from the sediment-trap rate (this simulation was only ran for the farm site where data were available), and (3) only material incorporated into sediments is simulated, which excludes POM that is removed from the site via all possible physical transport mechanisms, including advection and bedload transport. Scenario 3 is the optimized, SFM model-predicted, annual mean POM flux and assumes that the $\mathrm{NH}_{4}{ }^{+}$flux from the sediment is a good indicator of POM deposition after the model has accounted for diagenesis, nitrification, denitrification, burial, and mixing. The observed deposition of POM measured in sediment traps varied by season and station, where POM deposition was higher in the summer (especially June) and this peak was accentuated near the oyster floats as a result of increased oyster filtration and biodeposition rates. To accommodate this seasonal variability, the annual mean POM fluxes computed by SFM were transformed into seasonally-varying rates to represent the seasonal cycle of the depositional fluxes observed in the sediment traps. To achieve this, the interpolated monthly record was scaled so that the annual sum of the daily interpolated POM flux matched that of the POM depositional flux calculated in SFM. Initial conditions were determined by running the model for a $15 \mathrm{yr}$ simulation period with a deposition record derived for the Choptank River by Brady et al. (2013). The model simulation period began in 1985 (after $15 \mathrm{yr}$ of spin up) and ran through 2005, using the Hooke-Jeeves pattern search algorithm derived from a multi-year nutrient and $\mathrm{O}_{2}$ flux record from a site close to the farm $\left(38.6307^{\circ} \mathrm{N}, 76.1474^{\circ} \mathrm{W}\right)$. Since the farm was established in 2006, we simulated the seasonal deposition rates determined for the 3 stations (from 2011 observations) for each year during the 2006-2011 period. Thus, the total simulation period was from 19852011. 


\section{RESULTS}

\section{Site-specific differences in organic matter deposition}

POM deposition was greatest within the farm site, and declined with distance from the farm (Fig. 3). At the farm site, modeled annual average particulate organic nitrogen (PON) deposition was $162.8 \mathrm{mmol} \mathrm{N}$ $\mathrm{m}^{-2} \mathrm{~d}^{-1}$. This estimate includes the assumption that all PON collected in the off-bottom sediment traps was incorporated and processed in the underlying sediments (i.e. no resuspension correction). Under the same assumption, the near-farm site $(\sim 350 \mathrm{~m}$ from the closest oyster float) and reference site PON deposition comprised $48.3 \%\left(78.7 \mathrm{mmol} \mathrm{N} \mathrm{m}^{-2} \mathrm{~d}^{-1}\right.$ ) and $33.3 \%\left(54.2 \mathrm{mmol} \mathrm{N} \mathrm{m}^{-2} \mathrm{~d}^{-1}\right)$ of the farm deposition, respectively. By using the resuspension correction on the sediment trap estimates at the farm site, PON loading was reduced from 162.8 to $79.0 \mathrm{mmol}$ $\mathrm{N} \mathrm{m}{ }^{-2} \mathrm{~d}^{-1}$. Finally, if the Hooke-Jeeves algorithm (Brady et al. 2013) is used to back-calculate deposition based on observed $\mathrm{NH}_{4}{ }^{+}$flux, the resulting PON deposition would be 8.09, 4.08, and $1.92 \mathrm{mmol} \mathrm{N} \mathrm{m}^{-2}$ $\mathrm{d}^{-1}$ at the farm, near-farm, and reference sites, respectively. Essentially, these model-based results imply that only $3-5 \%$ of the material caught in the off-bottom traps was incorporated into the sediment. However, the results also indicate that PON incorporation into the sediment at the farm site was 4.2 times greater than the reference site.

\section{$\mathrm{NH}_{4}{ }^{+}$fluxes}

The observed annual average $\mathrm{NH}_{4}{ }^{+}$fluxes at the farm, near-farm, and reference sites were 394, 127, and $21.8 \mu \mathrm{mol} \mathrm{N} \mathrm{m}^{-2} \mathrm{~h}^{-1}$, respectively. Only at the farm site did it appear that sediment-water $\mathrm{NH}_{4}{ }^{+}$ fluxes increased substantially following the implementation of oyster culture (Fig. 4). While it is clear that $\mathrm{NH}_{4}{ }^{+}$fluxes at the farm site were elevated compared to the reference site, SFM estimates based on the sediment trap observations indicated that the farm $\mathrm{NH}_{4}{ }^{+}$fluxes could have been 6 to 19 times greater (2520-7570 $\mu \mathrm{mol} \mathrm{N} \mathrm{m}^{-2} \mathrm{~h}^{-1}$ ) depending on whether sediment trap observations were corrected for resuspension. The estimates of annual $\mathrm{NH}_{4}{ }^{+}$flux based on model-data fitting were closely matched to observed fluxes at all stations (i.e. 388, 110, and 17.6 $\mu \mathrm{mol} \mathrm{N} \mathrm{m} \mathrm{N}^{-2} \mathrm{~h}^{-1}$ at the farm, near-farm, and reference sites, respectively) (Fig. 5). The mean error between observed and modeled $\mathrm{NH}_{4}{ }^{+}$fluxes was

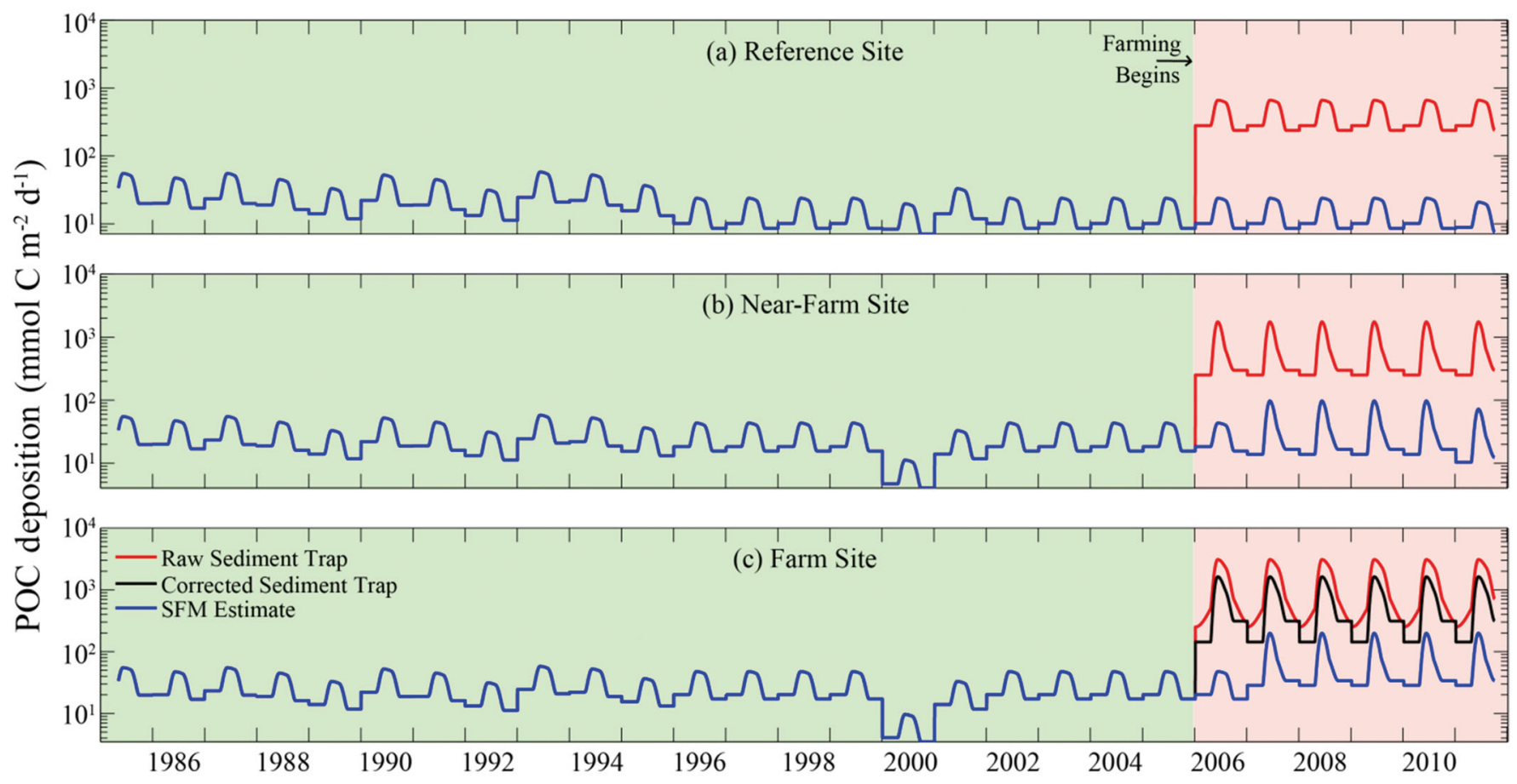

Fig. 3. Time-series (1985-2011) of particulate organic carbon (POC) deposition to sediments at (a) reference, (b) near-farm, and (c) farm sites. Green and red shading indicates pre- and post-oyster farming periods, respectively. Red line: uncorrected raw sediment trap estimates, black line: farm site sediment trap estimates corrected for resuspension, blue line: deposition estimated by sediment flux model (SFM) by fitting deposition to the observed sediment-water $\mathrm{NH}_{4}{ }^{+}$fluxes 


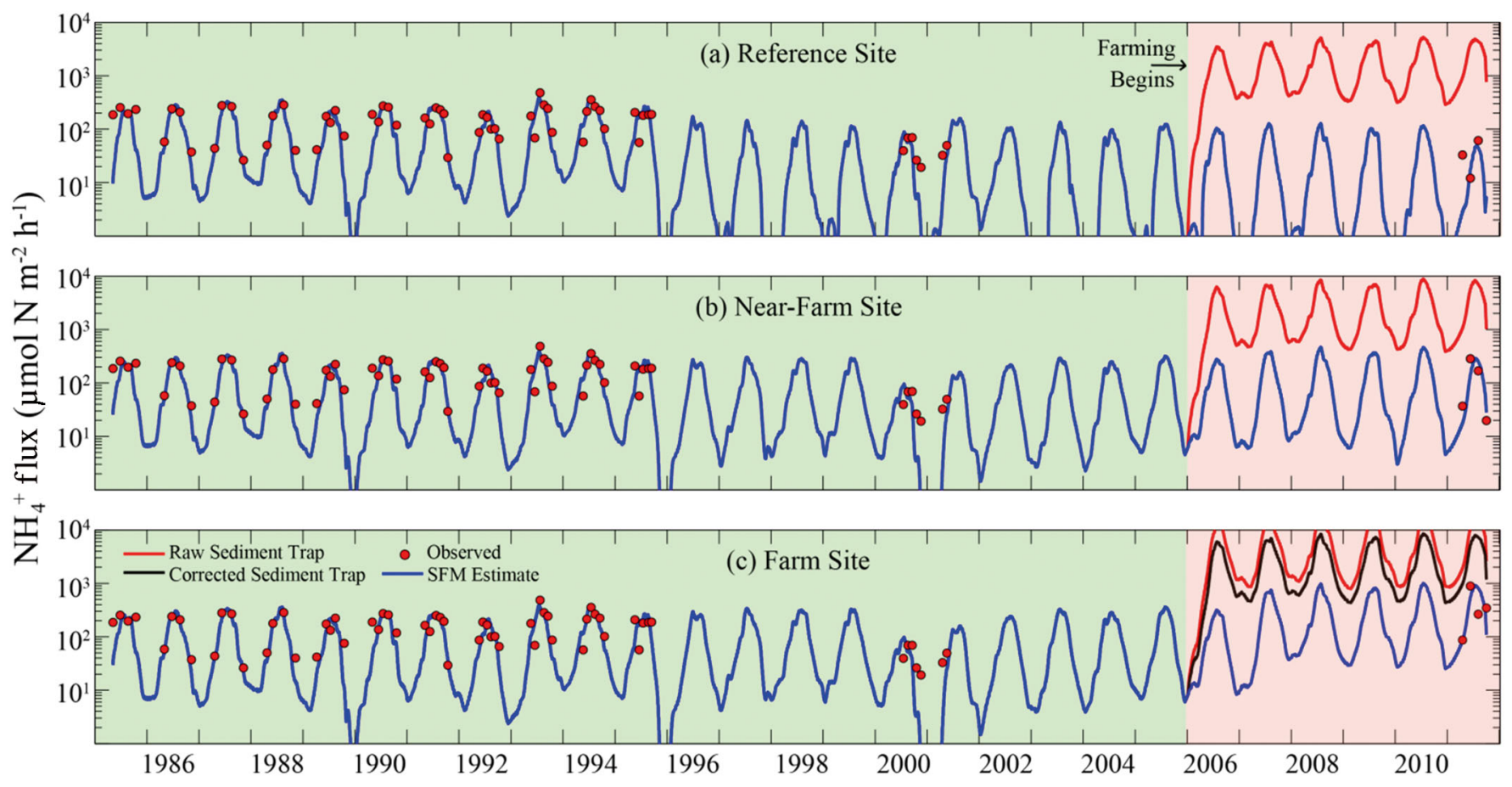

Fig. 4. Time-series (1985-2011) of modeled (lines) and observed (red circles) $\mathrm{NH}_{4}{ }^{+}$fluxes at (a) reference, (b) near-farm, and (c) farm sites. Green and red shading indicates pre- and post-oyster farming periods, respectively. Red line: uncorrected raw sediment trap estimates, black line: farm site sediment trap estimates corrected for resuspension, blue line: deposition estimated by sediment flux model (SFM) by fitting deposition to the observed sediment-water $\mathrm{NH}_{4}{ }^{+}$fluxes
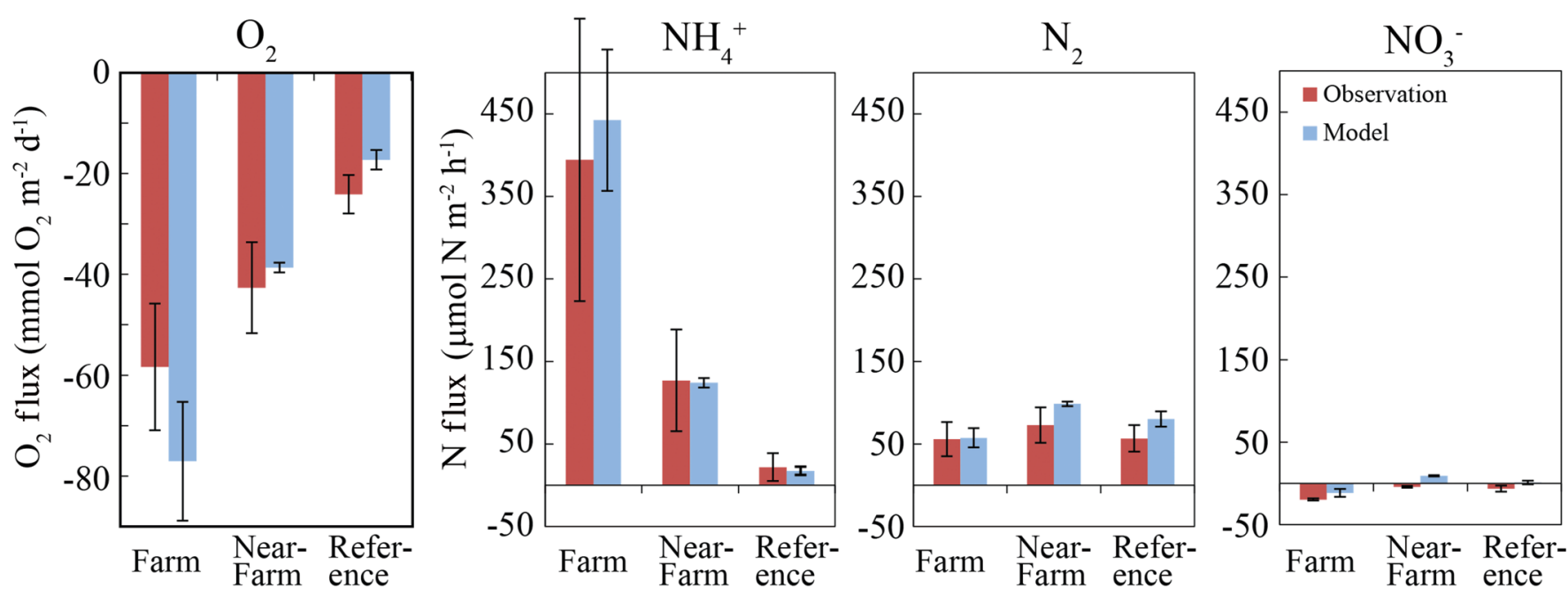

Fig. 5. Comparison of $\mathrm{SFM} \mathrm{O}_{2}, \mathrm{NH}_{4}{ }^{+}, \mathrm{N}_{2}$, and $\mathrm{NO}_{3}{ }^{-}$fluxes with observed fluxes at the reference, near-farm, and farm sites. For observations, data are the means $( \pm \mathrm{SE})$ over the 4 sampling dates between April-September. For model simulations, data are means $( \pm \mathrm{SE})$ over each month

$8.9 \mu \mathrm{mol} \mathrm{N} \mathrm{m}^{-2} \mathrm{~h}^{-1}$ across all stations (Table 3). It should be noted that while PON deposition was approx. 50\% lower at the near-farm site than within the farm ( $350 \mathrm{~m}$ away), $\mathrm{NH}_{4}{ }^{+}$flux at the near-farm site was a third of the farm $\mathrm{NH}_{4}{ }^{+}$flux. The model indicates that this reduction in $\mathrm{NH}_{4}{ }^{+}$flux was associ- ated with enhanced nitrification-denitrification coupling, as seen in the reduced nitrogen recycling efficiency at the near-farm and reference site. Nitrification is under strong temperature control and typically decreases during winter months (i.e. DecemberJanuary). Interestingly, modeled $\mathrm{NH}_{4}{ }^{+}$flux at the 
Table 3. Root mean square error (RMSE), reliability index (RI), mean error $(\mathrm{ME})$, correlation coefficient ( $\mathrm{r}$ ), and relative error (RE) for model-data comparison of sediment-water $\mathrm{NO}_{3}{ }^{-}, \mathrm{PO}_{4}{ }^{3-}, \mathrm{NH}_{4}{ }^{+}, \mathrm{O}_{2}$, and $\mathrm{N}_{2}$ fluxes. April to September conditions at the farm site were as follows (mean values): salinity $=8.2, \mathrm{O}_{2}=245.8 \mu \mathrm{M}, \mathrm{NO}_{3}{ }^{-}=6.4 \mu \mathrm{M}, \mathrm{NH}_{4}{ }^{+}=6.4 \mu \mathrm{M}, \mathrm{PO}_{4}{ }^{3-}=0.35 \mu \mathrm{M}$

\begin{tabular}{|lcrrrl|}
\hline Flux & $\begin{array}{c}\text { RMSE } \\
\left(\mu \mathrm{mol} \mathrm{m}^{-2} \mathrm{~h}^{-1}\right)\end{array}$ & RI & ME & $\mathrm{r}$ & $\mathrm{RE}$ \\
\hline$J\left[\mathrm{NO}_{3}{ }^{3-}\right]$, high sorption & 14.21 & 1.33 & -10.57 & 0.79 & -1.19 \\
$J\left[\mathrm{PO}_{4}{ }^{3-}\right.$, low sorption & 28.7 & 1.47 & -20.98 & 0.05 & -2.1 \\
$J\left[\mathrm{PO}_{4}{ }^{3-}\right]$, low & 1.48 & -22.51 & 0.07 & -2.25 \\
$J\left[\mathrm{NH}_{4}{ }^{+}\right]$ & 201.66 & 1.51 & 8.87 & 0.65 & 0.66 \\
$J\left[\mathrm{O}_{2}\right]$ & 26.42 & 1.37 & 3.89 & 0.68 & 0.44 \\
$J\left[\mathrm{~N}_{2}\right]$ & 35.84 & 1.46 & -14.24 & 0.39 & 1.46 \\
\hline
\end{tabular}

SOD of $68.6,29.5$, and $15.2 \mathrm{mmol} \mathrm{O}_{2} \mathrm{~m}^{-2}$ $\mathrm{d}^{-1}$ at the same locations. The Reliability Index across all observations was 1.37 and the mean error only $3.89 \mathrm{mmol} \mathrm{O}_{2}$ $\mathrm{m}^{-2} \mathrm{~d}^{-1}$ (Table 3). While PON deposition was adjusted to match $\mathrm{NH}_{4}^{+}$flux, no calibration or adjustments were made to predict SOD. Model and observations support the potential of biodeposition to approximately double the sediment oxygen demand in sediments even though only $3-11 \%$ of the potential POM was processed in the sediment. The largest model-observation mismatch came at the farm in winter was 2 orders of magnitude greater than winter $\mathrm{NH}_{4}{ }^{+}$fluxes at the reference site (11.3 vs. $0.154 \mu \mathrm{mol} \mathrm{N} \mathrm{m}{ }^{-2} \mathrm{~h}^{-1}$ ) (Fig. 4).

\section{$\mathrm{NO}_{3}{ }^{-}$fluxes}

Observed and modeled $\mathrm{NO}_{3}{ }^{-}+\mathrm{NO}_{2}{ }^{-}$(hereafter $\mathrm{NO}_{3}{ }^{-}$) fluxes were relatively small compared to $\mathrm{NH}_{4}{ }^{+}$fluxes and denitrification rates (Fig. 5). Observed $\mathrm{NO}_{3}{ }^{-}$ fluxes were $-19.6,-4.08$, and $-6.33 \mu \mathrm{mol} \mathrm{N} \mathrm{m} \mathrm{N}^{-2} \mathrm{~h}^{-1}$ at the farm, near-farm, and reference sites, respectively. The corresponding modeled fluxes were $-4.96,3.89$, and $2.76 \mu \mathrm{mol} \mathrm{N} \mathrm{m}^{-2} \mathrm{~h}^{-1}$. Although the mean error was $-10.6 \mu \mathrm{mol} \mathrm{N} \mathrm{m}^{-2} \mathrm{~h}^{-1}$, the model captured much of the dynamics of the system as evidenced by a reliability index of 1.33 and model-data correlation coefficient of 0.79 (Table 3). The model correctly captured the relative rankings of the $\mathrm{NO}_{3}{ }^{-}$ fluxes at the 3 sites, as well as the seasonal signal within each site. For example, if we consider the near-farm site, the combination of higher PON deposition (Fig. 3) relative to the reference site and higher aerobic layer depth and nitrification rate relative to the farm site resulted in the highest $\mathrm{NO}_{3}{ }^{-}$fluxes at the near-farm site (as reflected in the observations and the model simulations). It is worth noting that in our simulations here, we reduced the sediment nitrification reaction velocity (Di Toro 2001) from 0.13 to $0.1 \mathrm{~m} \mathrm{~d}^{-1}$ to yield the optimal model-data agreement.

\section{Sediment oxygen demand}

Annual average observed sediment oxygen demand (SOD) at the farm, near-farm, and reference sites was 51.8, 37.9, and $21.4 \mathrm{mmol} \mathrm{O}_{2} \mathrm{~m}^{-2} \mathrm{~d}^{-1}$, respectively. Model results compare favorably to the observations (Fig. 6), as evidenced by annual average modeled farm site August sampling event. Although the overlying water column was not observed to go hypoxic, the model predicts a substantial sulfide build up associated with elevated sulfate reduction rates, with approx. $50 \%$ higher sulfide concentrations in the anaerobic layer at the farm site compared to the reference site (data not shown).

\section{Denitrification}

We compared model estimates of sediment denitrification to observations of net sediment $\mathrm{N}_{2}$ fluxes measured in dark incubations. The observed annual average $( \pm \mathrm{SD})$ net $\mathrm{N}_{2}$ fluxes (which we equate to denitrification) at the farm, near-farm, and reference sites were $55.8 \pm 20.8,72.8 \pm 21.4$, and $56.6 \pm 16.1$ umol $\mathrm{N} \mathrm{m}^{-2} \mathrm{~h}^{-1}$, respectively. Both modeled and observed $\mathrm{N}_{2}$ fluxes were comparable in magnitude and seasonality across sites, with peak fluxes during June and minima in April and August. For example, modeled denitrification rates, averaged over the same period as the observations, were $57.4 \pm 11.7$ (mean $\pm \mathrm{SD}$ ) $\mu \mathrm{mol} \mathrm{N} \mathrm{m}^{-2} \mathrm{~h}^{-1}$ at the farm site and $80.1 \pm 9.2 \mu \mathrm{mol} \mathrm{N} \mathrm{m}{ }^{-2} \mathrm{~h}^{-1}$ at the reference site. Unlike the $\mathrm{NH}_{4}{ }^{+}$fluxes (and also $\mathrm{PO}_{4}{ }^{3-}$ and $\mathrm{O}_{2}$ fluxes summarized below), modeled $\mathrm{N}_{2}$ fluxes were similar in the 3 depositional scenarios, where $\mathrm{N}_{2}$ fluxes were slightly higher under the lowest $\mathrm{PON}$ deposition rates (Fig. 7). Whilst denitrification usually follows an annual cycle that closely matches temperature in oxic environments, with relatively deep $\mathrm{O}_{2}$ penetration into sediments (i.e. during the period 2000-2005; Fig. 7 \& 8), model computations and observations suggest that denitrification became limited in warm months (August) in the years when PON deposition rates were elevated following the initiation of aquaculture in 2006 (Fig. 7). Such reduced late-summer denitrification (particularly 2007-2009) was associated 


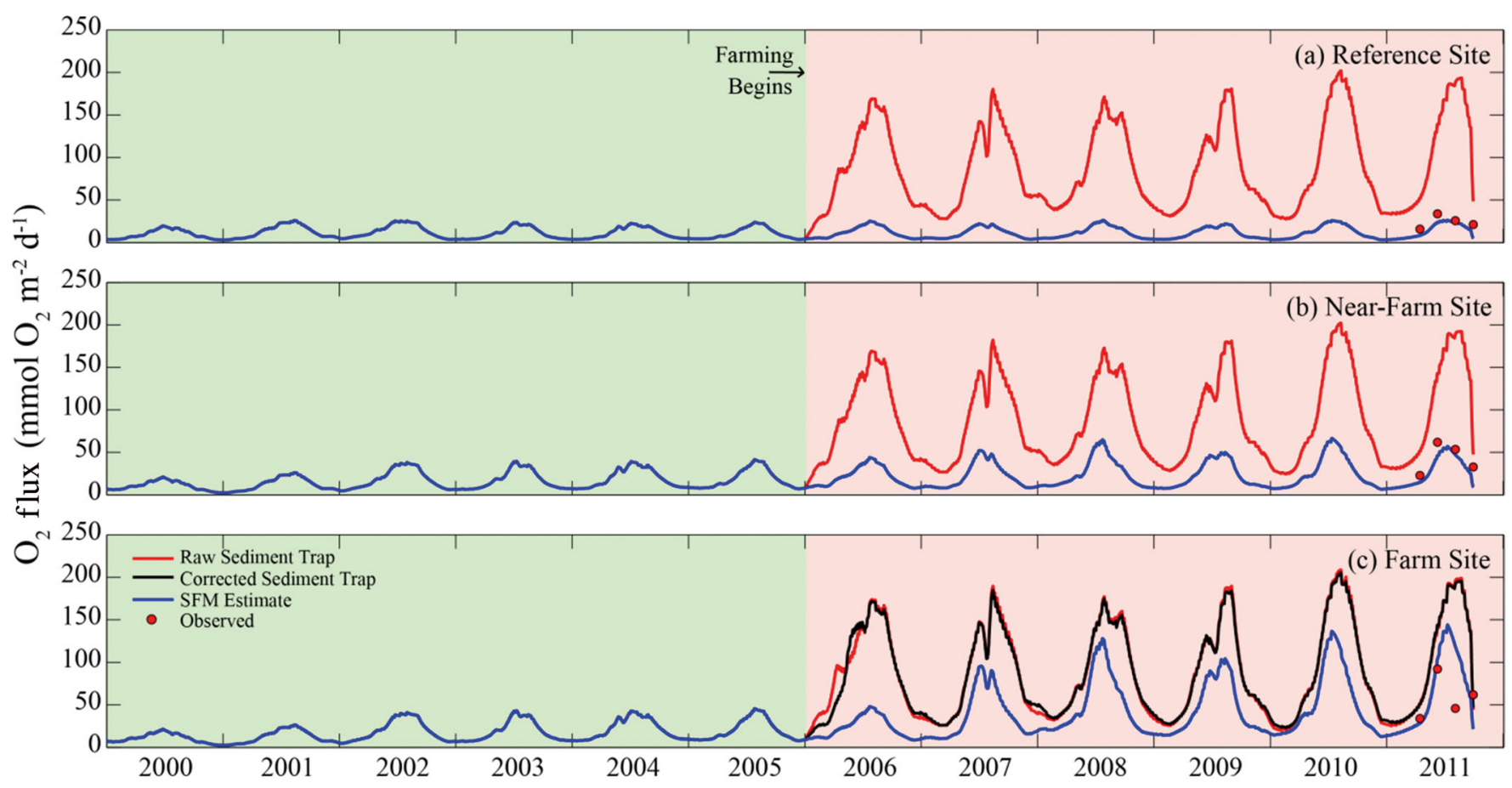

Fig. 6. Time-series (2000-2011) of modeled (lines) and observed (red circles) $\mathrm{O}_{2}$ fluxes at (a) reference, (b) near-farm, and (c) farm sites. Green and red shading indicates pre- and post-oyster farming periods, respectively. Red line: uncorrected raw sediment trap estimates, black line: farm site sediment trap estimates corrected for resuspension, blue line: deposition estimated by sediment flux model (SFM) by fitting deposition to the observed sediment-water $\mathrm{NH}_{4}{ }^{+}$fluxes

with reduced aerobic layer depths (Fig. 8). Despite this seasonal alteration due to higher PON deposition rates, the overall annual magnitude of sediment denitrification did not change in response to the introduction of the aquaculture operation.

\section{Aerobic layer depth}

A striking difference between the different POM deposition scenarios is the depth of the modeled aerobic layer. Model simulations suggest that once aquaculture activities began in 2006, the aerobic layer depth decreased markedly, especially at the farm site (Fig. 8). For example, using SFM-derived estimates of deposition, aerobic layer depth at the farm and near-farm sites were $\sim 50 \%$ and $\sim 75 \%$ of the reference site aerobic layer depth, respectively. At all sites, the seasonal maxima in aerobic layer depth during winter months were particularly reduced (e.g. from 2 to $<1 \mathrm{~mm}$ at the near-farm site) (Fig. 8). During summer, reductions in the aerobic layer depth occurred despite the absence of severe water-column $\mathrm{O}_{2}$ depletion in the overlying water, where a YSI ${ }^{\circledR} 6600$ sensor deployed within the farm during August of 2011 never recorded $\mathrm{O}_{2}$ concentrations $<125 \mu \mathrm{M}$.

\section{$\mathrm{PO}_{4}{ }^{3-}$ fluxes}

Observed $\mathrm{PO}_{4}{ }^{3-}$ fluxes were relatively small $(-10.8$ to $9.8 \mu \mathrm{mol} \mathrm{P} \mathrm{m}^{-2} \mathrm{~h}^{-1}$ ) throughout our study relative to fluxes typical of deep Chesapeake Bay habitats (e.g. 30-100 $\mu \mathrm{mol} \mathrm{P} \mathrm{m}{ }^{-2} \mathrm{~h}^{-1}$ at depths $>10 \mathrm{~m}$ ), but were consistent with values expected for shallow systems with relatively high $\mathrm{O}_{2}$ in overlying water (Fig. 9). Although observed $\mathrm{PO}_{4}{ }^{3-}$ fluxes, when averaged over the 4 sampling dates (April-September), were $-1.4,-0.09$, and

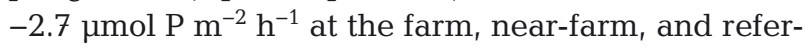
ence sites, respectively, model-predictions averaged over the same period using previously determined solid-solute partitioning coefficients (Testa et al. 2013) were much higher $\left(24.2,8.5,3.5 \mu \mathrm{mol} \mathrm{P} \mathrm{m}{ }^{-2} \mathrm{~h}^{-1}\right.$ at the farm, near-farm, and reference sites, respectively). Because the oyster farm site may have iron-rich sediments with a higher capacity to bind $\mathrm{PO}_{4}{ }^{3-}$ than typical Chesapeake Bay sediments, we increased the phosphorus partitioning coefficients from 300 to $400 \mathrm{l} \mathrm{kg}^{-1}$ in the aerobic layer and from 100 to $200 \mathrm{l} \mathrm{kg}^{-1}$ in the anaerobic layer. As a result, sediment-water $\mathrm{PO}_{4}{ }^{3-}$ fluxes decreased $82,88.6$, and $98 \%$ at the farm, nearfarm, and reference sites, respectively, resulting in mean $( \pm \mathrm{SD})$ fluxes of $4.5 \pm 1.1,0.98 \pm 0.18$, and $0.06 \pm$ $0.06 \mu \mathrm{mol} \mathrm{P} \mathrm{m}{ }^{-2} \mathrm{~h}^{-1}$, which were much closer to fluxes observed at the sites (Table 3, Fig. 9). 


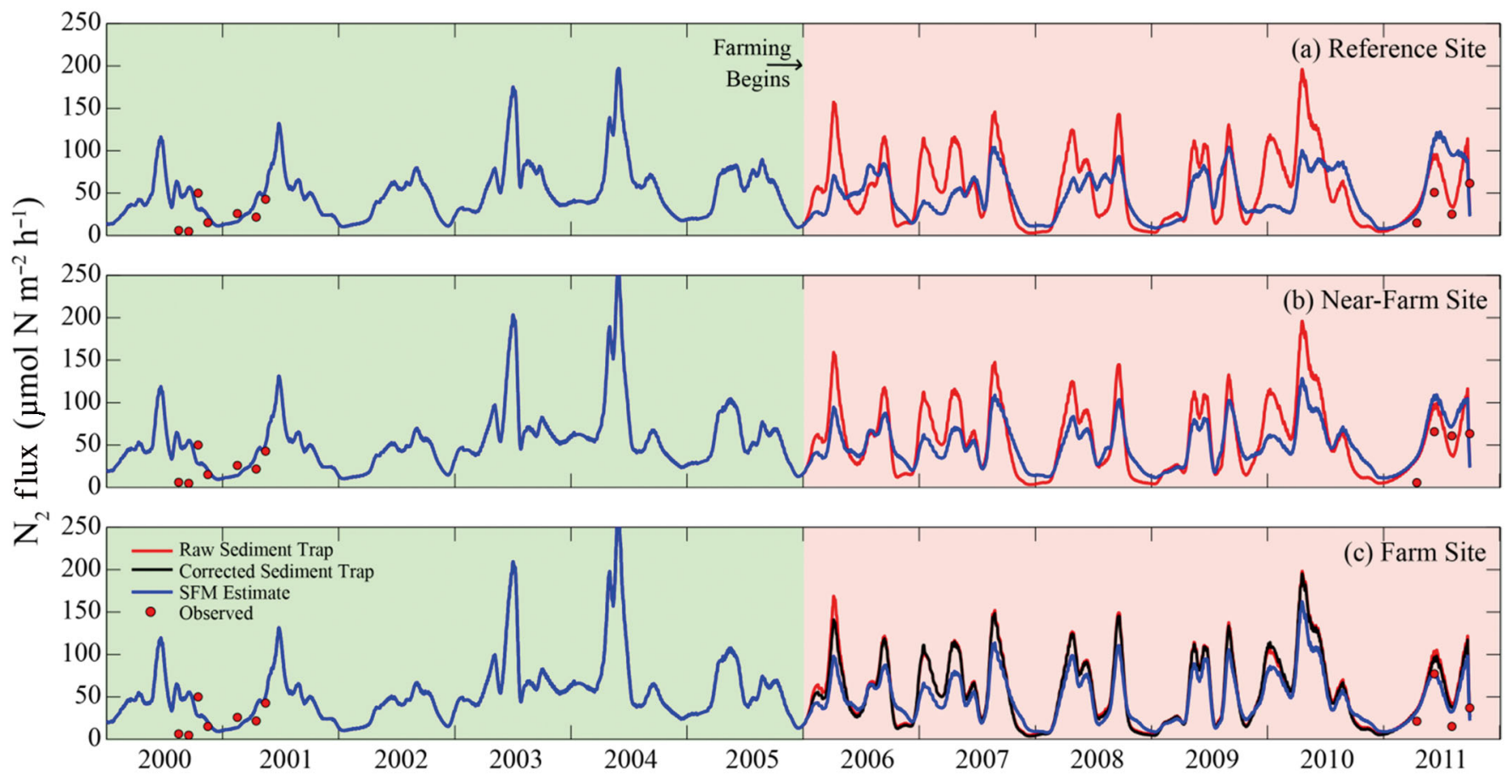

Fig. 7. Time-series (2000-2011) of modeled (lines) and observed (red circles) $\mathrm{N}_{2}$ fluxes at (a) reference, (b) near-farm, and (c) farm sites. Green and red shading indicates pre- and post-oyster farming periods, respectively. Red line: uncorrected raw sediment trap estimates, black line: farm site sediment trap estimates corrected for resuspension, blue line: deposition estimated by sediment flux model (SFM) by fitting deposition to the observed sediment-water $\mathrm{NH}_{4}{ }^{+}$fluxes

\section{Farm impacts on nitrogen cycling}

Upon comparing changes in nitrogen cycling due to proximity-to-farm associated differences in PON deposition, several key points can be made. Firstly, PON deposition to sediments decreased with increasing distance from the farmi PON deposition was $420 \mu \mathrm{mol} \mathrm{N}$ $\mathrm{m}^{-2} \mathrm{~h}^{-1}$ at the farm relative to $75 \mu \mathrm{mol} \mathrm{N} \mathrm{m}{ }^{-2} \mathrm{~h}^{-1}$ at the reference site, resulting in comparably reduced diagenesis rates and sediment-water $\mathrm{NH}_{4}{ }^{+}$fluxes (Fig. 10). Secondly, although $\mathrm{NO}_{3}{ }^{-}$fluxes were minimal relative to $\mathrm{NH}_{4}{ }^{+}$, denitrification, and nitrification (Fig. 10), nitrification and denitrification were elevated at the reference and near-farm sites relative to the farm site. Consequently, the nitrogen recycling efficiency $[\mathrm{NRE}=$ $\mathrm{NH}_{4}{ }^{+}$flux/ $\left(\mathrm{NH}_{4}{ }^{+}\right.$flux $+\mathrm{NO}_{3}{ }^{-}$flux $+\mathrm{N}_{2}$ flux $\left.) \times 100\right]$ at the sites decreased markedly with distance from the farm, where nearly all of the $\mathrm{N}$ fluxes were derived from $\mathrm{NH}_{4}{ }^{+}$fluxes at the farm site, while $\mathrm{NH}_{4}{ }^{+}$was $<$ $30 \%$ of all $\mathrm{N}$ fluxes at the reference site (Fig. 10).

\section{Nitrogen budget at the farm site}

By using the suite of simulations carried out for 2011, we generated a nitrogen budget of the farm site (Fig. 11). Perhaps the most striking feature of the budget is that if we consider the sediment trap measurements used to drive the model, background deposition and oyster biodeposition would potentially result in the deposition of $3714 \mu \mathrm{mol} \mathrm{N} \mathrm{m}{ }^{-2} \mathrm{~h}^{-1}$, while model simulations suggest that only $425 \mu \mathrm{mol} \mathrm{N} \mathrm{m}{ }^{-2}$ $\mathrm{h}^{-1}$ would actually have been deposited to sediments. This suggests that $3289 \mu \mathrm{mol} \mathrm{N} \mathrm{m}{ }^{-2} \mathrm{~h}^{-1}$ was exported from the system via some mechanism(s) of horizontal transport under normal conditions and/or during storm events. This represents an export of $88.6 \%$ of the material potentially processed within the farm. Of the PON that was incorporated into the sediments, $80 \%$ was released back to the water column as $\mathrm{NH}_{4}{ }^{+}$, while only $10 \%$ was lost permanently via denitrification and $10 \%$ was buried (Fig. 11). Because this budget includes annual mean fluxes and discounts changes in storage within the sediment, slight imbalances in the budget exist (Fig. 11).

\section{DISCUSSION}

Deposition of POM was clearly elevated at the oyster farm site relative to multiple locations within a kilometer of the farm. Moreover, sediment trap and 


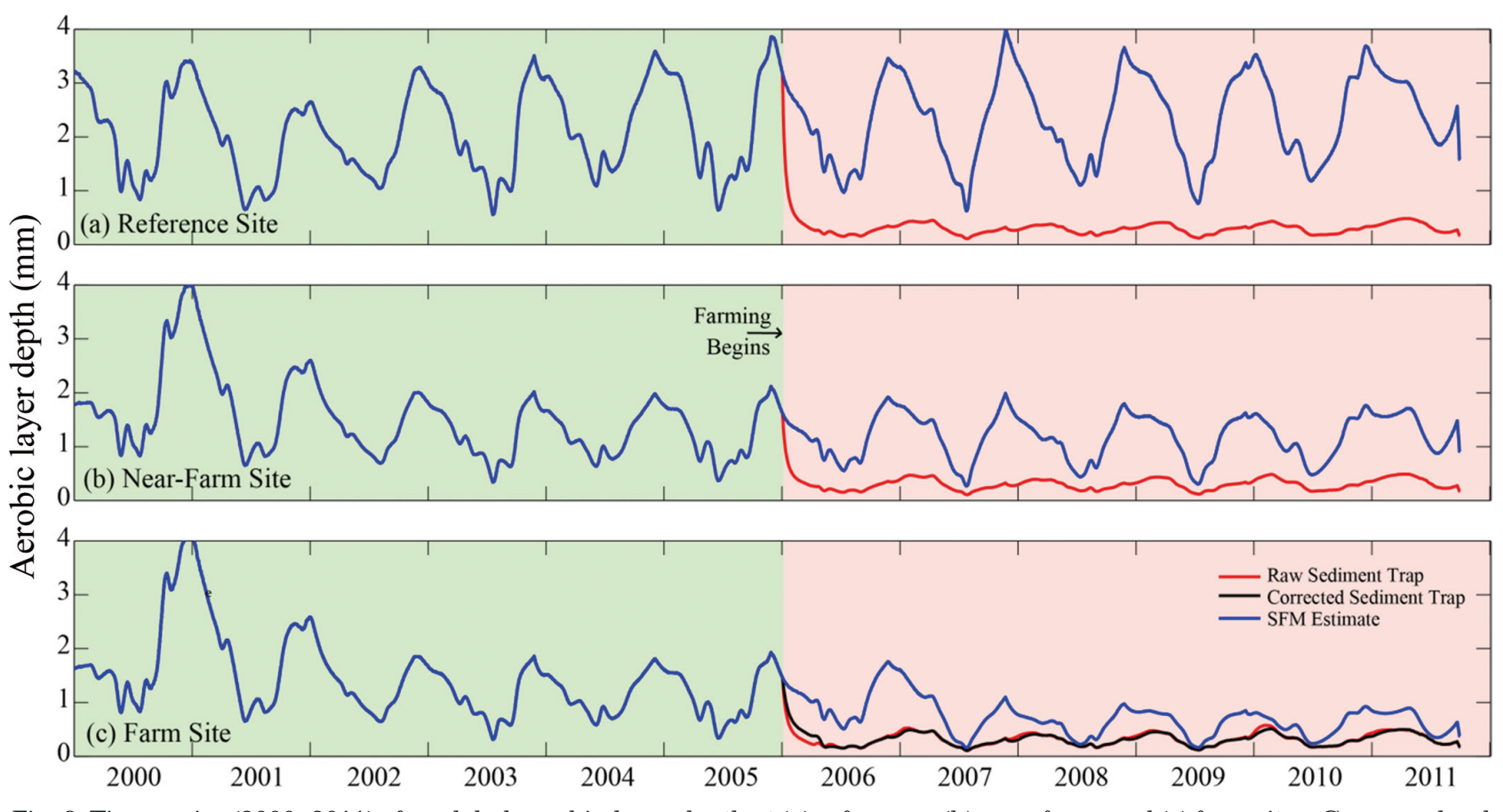

Fig. 8. Time-series (2000-2011) of modeled aerobic-layer depth at (a) reference, (b) near-farm, and (c) farm sites. Green and red shading indicates pre- and post-oyster farming periods, respectively. Red line: uncorrected raw sediment trap simulation at the farm site, black line: farm site sediment trap estimates corrected for resuspension, blue line: simulation where deposition was estimated by sediment flux model (SFM) by fitting deposition to the observed sediment-water $\mathrm{NH}_{4}{ }^{+}$fluxes

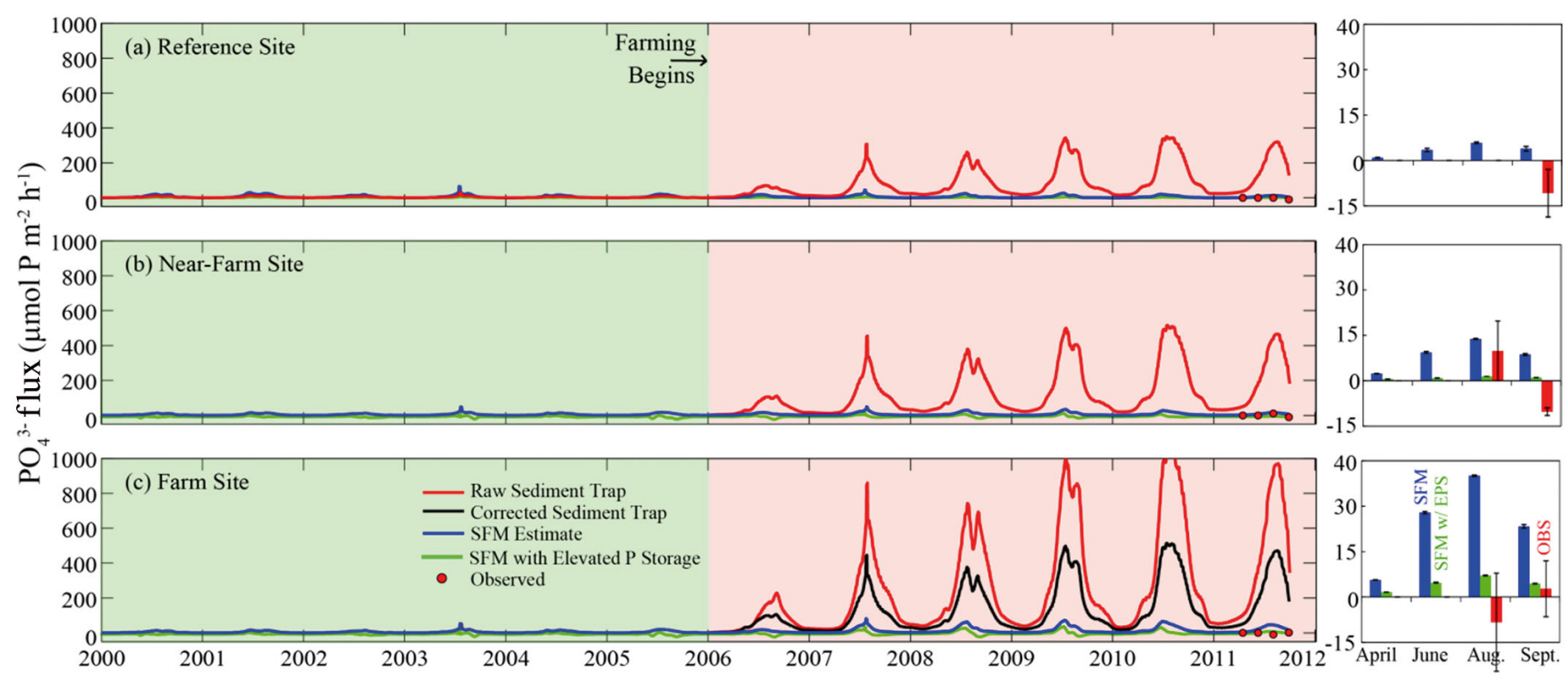

Fig. 9. (Left) Time-series (2000-2011) of modeled (lines) and observed (red circles) $\mathrm{PO}_{4}{ }^{3-}$ fluxes at (a) reference, (b) near-farm, and (c) farm sites. Green and red shading indicates pre- and post-oyster farming periods, respectively. Red line: simluation based on uncorrected raw sediment trap estimates, black line: simulation where sediment trap estimates were corrected for resuspension at the farm site, blue line: simulation where deposition was estimated by sediment flux model (SFM) by fitting deposition to the observed sediment-water $\mathrm{NH}_{4}{ }^{+}$fluxes, green line: SFM simulation with enhanced sorption capacity in sediments. (Right) OBS, red: observations are compared to the 2 SFM simulations over each month of the experimental study. SFM, blue: model simulations with typical sorption capacity. SFM w/EPS, green: sediment flux models with enhanced sorption capacity 


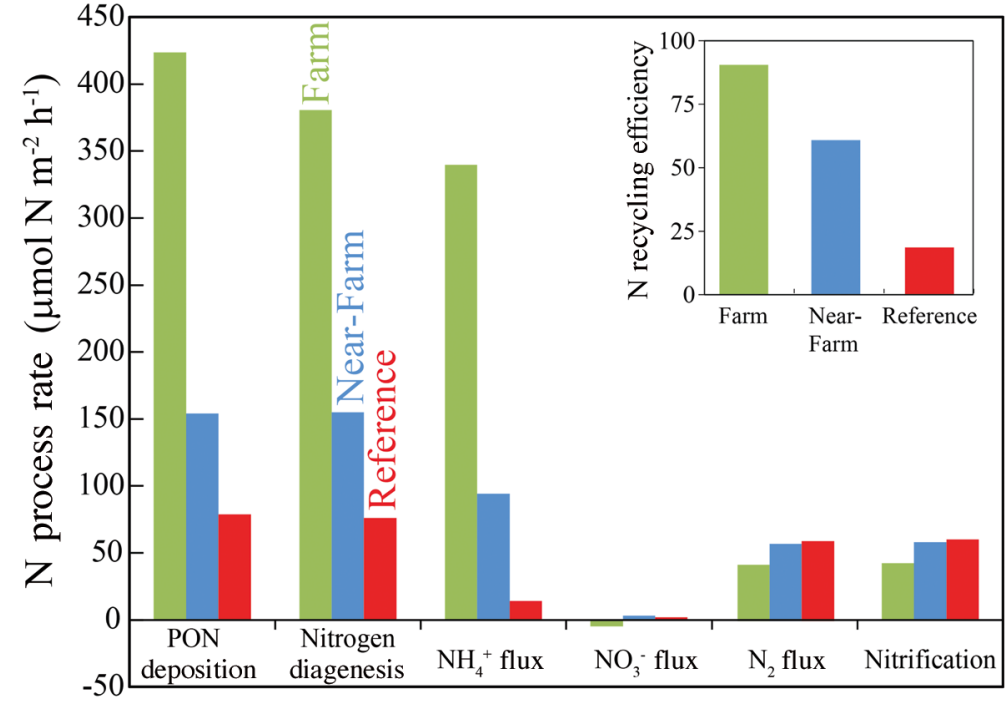

Fig. 10. Comparison of annual means of major nitrogen processes within the sediment at the farm, near-farm, and reference sites. The inset shows nitrogen recycling efficiency (NRE) at each site in 2011. $\mathrm{NRE}=\mathrm{NH}_{4}{ }^{+}$ flux $\div\left(\mathrm{NH}_{4}{ }^{+}\right.$flux $+\mathrm{NO}_{3}{ }^{-}$flux $+\mathrm{N}_{2}$ flux $) \times 100$

model-derived estimates of POM deposition were about 3.6 and 4.2 times greater, respectively, within the farm than at an adjacent reference site (Table 2). This increase is almost certainly due to the filtering of ambient particulates by cultured oysters and subsequent excretion of feces and pseudofeces resulting in the sinking of biodeposits to sediments. Although this conclusion is unsurprising, the fact that observed POM deposition rates were 3 times larger at the farm than at a nearby reference site ( $700 \mathrm{~m}$ to the southeast) reveals that POM originating from the farm does not accumulate substantially in the immediate surrounding areas. In addition, model results indicate that $\mathrm{POC}$ deposition at the reference site did not increase following the initiation of farming in 2006 (Fig. 3). These findings indicate that large amounts of POM originally concentrated within the farm are widely distributed over a short period.

Likely mechanisms for this substantial POM export include resuspension and subsequent horizontal transport during wind events, added to normal tidal advective transport. Dominant ebb tides at this location transport POM northward, away from the farm and into the open Choptank River estuary (Fig. 1), where the material is effectively dispersed. Both wave observations and wave modeling (data not shown) indicate that winds of modest strength (5-10 $\mathrm{m} \mathrm{s}^{-1}$ ) from the NW to the NE (relatively common) or similar winds from the SE (less common) are capable of generating large enough waves $(0.5 \mathrm{~m})$ to resuspend significant amounts of sediment in these shallow waters. None

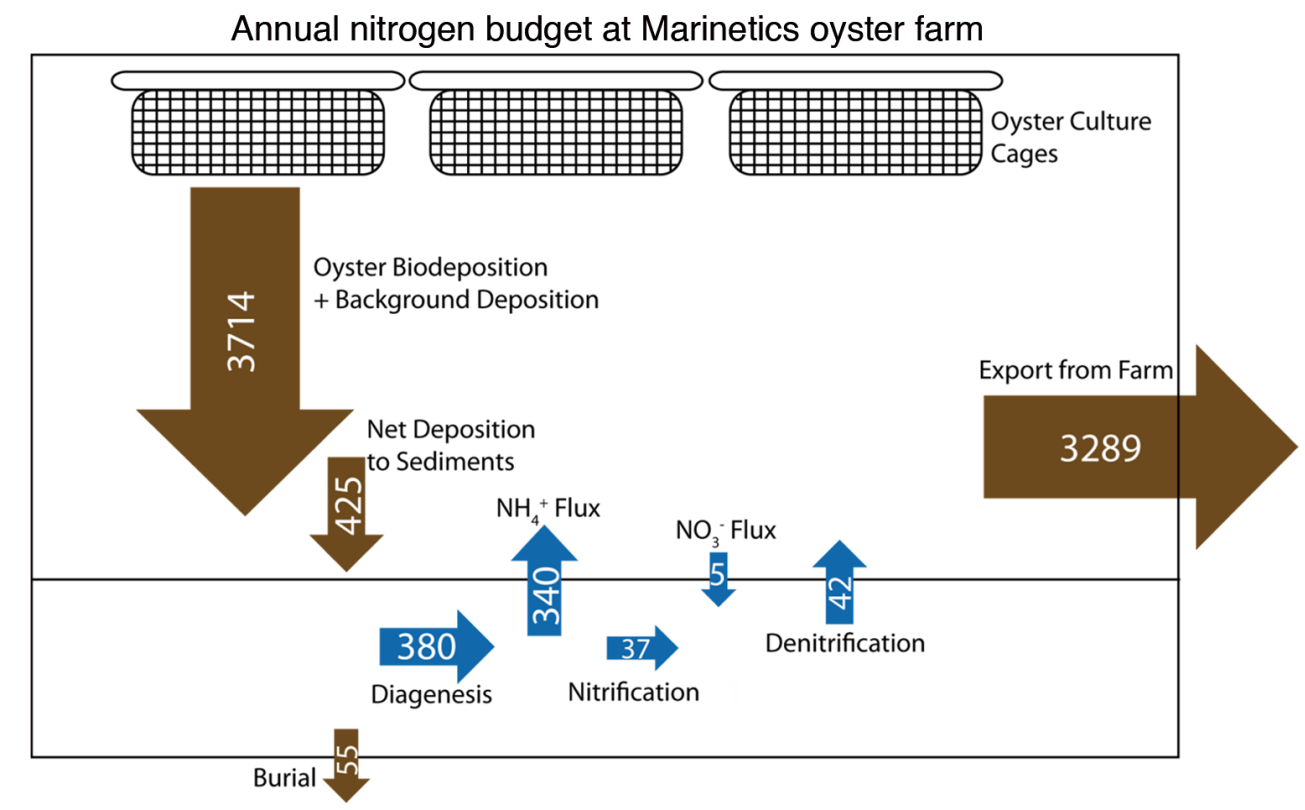

Fig 11. Annual nitrogen budget for the Marinetics oyster farm. Brown arrows represent physical transport, while blue arrows represent biogeochemical fluxes. Clearly, the majority of the material that could potentially be integrated into the sediments is exported from the site before biogeochemical transformation could occur. $\mathrm{NH}_{4}{ }^{+}$fluxes dominate the sediment-water exchanges. All units in $\mu \mathrm{mol} \mathrm{m} \mathrm{m}^{-2} \mathrm{~h}^{-1}$ 
of the $24 \mathrm{~h}$ sediment trap deployments occurred during such a wind wave event, however. Thus, although the farm concentrates large amounts of POM that sink below the cages, there does not appear to be a large 'footprint' of the farm in terms of excessive POM accumulation in adjacent sediments (Table 1).

As a result of the sensitivity of this site to wave and tide-induced resuspension and transport, we calculated that only $11 \%$ of the organic material settling below the oyster cages is eventually processed within the sediment at the farm (Fig. 11). Marinetics oyster farm is thus situated in an ideal location for floating oyster aquaculture, as the physical setting (hydrodynamics and sediment transport) prevents the accumulation of large amounts of organic matter that otherwise would severely impact the sediments at the site (Figs. 4, $6 \& 8$ ), as has been observed elsewhere (Weise et al. 2009). In other locations, suspended shellfish farms (e.g. mussels, oysters) located at sites with slower currents and less resuspension suffered measurable degradation (e.g. sulfide production, nutrient release) with high POM accumulation (Grant et al. 2005, Holyoke 2008).

Although we conclude that the impact of the oyster culture at the Marinetics farm site on sediments is substantially lower than the potential impact given retention of all oyster-derived POM on site, we did observe higher $\mathrm{NH}_{4}{ }^{+}$effluxes and $\mathrm{O}_{2}$ influxes at the farm, consistent with comparable studies elsewhere (Giles et al. 2006). Model results suggest that $\mathrm{O}_{2}$ influxes and $\mathrm{NH}_{4}{ }^{+}$effluxes began to substantially increase a year after aquaculture was initiated (2007), especially at the farm site where both model simulations and observations indicated that they were 3-10 times higher than the reference site. These patterns should be expected, given elevated respiration under conditions of elevated organic carbon availability. The farm $\mathrm{NH}_{4}{ }^{+}$efflux computed from the observed $\mathrm{O}_{2}$ influx, assuming Redfield stoichiometry and a respiratory quotient of 1 , was $367 \mu \mathrm{mol} \mathrm{m}^{-2} \mathrm{~h}^{-1}$, which is close to the actual $\mathrm{NH}_{4}{ }^{+}$flux of $394 \mu \mathrm{mol} \mathrm{N} \mathrm{m}{ }^{-2} \mathrm{~h}^{-1}$ and implies that the majority of the $\mathrm{N}$ released during diagenesis at the farm is released back to the watercolumn, consistent with an elevated ' $\mathrm{N}$ recycling efficiency' (Fig. 10). In contrast, the $\mathrm{NH}_{4}{ }^{+}$efflux computed stoichiometrically at the reference site was $130 \mu \mathrm{mol} \mathrm{N} \mathrm{m}{ }^{-2} \mathrm{~h}^{-1}$ greater than observed, indicating that denitrification was removing $\mathrm{N}$ from the system. This latter pattern is also consistent with the fact that denitrification was similar across all sites (Fig. 5), thus removing a relatively larger fraction of inorganic $\mathrm{N}$ from the reference site, which had lower
$\mathrm{NH}_{4}{ }^{+}$fluxes. Comparable sediment denitrification rates, but different $\mathrm{NH}_{4}{ }^{+}$and $\mathrm{O}_{2}$ fluxes between reference and aquaculture sites have been observed elsewhere in Chesapeake Bay (Higgins et al. 2013). It is worth noting that our analysis considered only sediment denitrification, and does not consider $\mathrm{N}$ processes occurring within the aggregations of the cultured oysters themselves, where $\mathrm{NH}_{4}{ }^{+}$efflux, denitrification, and overall nitrogen cycling may be enhanced relative to adjacent sediments (Duarte et al. 2003, Kellogg et al. 2013).

The similar denitrification rates across the 3 varying POM deposition and $\mathrm{NH}_{4}{ }^{+} / \mathrm{O}_{2}$ flux environments suggest feedbacks within the nitrogen cycle that prevent denitrification inhibition under increasingly anaerobic conditions. In many enriched, muddy Chesapeake Bay sediments, low oxygen penetration restricts nitrification and thus coupled nitrification-denitrification (Kemp et al. 1990). Although benthic macrofauna can elevate $\mathrm{O}_{2}$ penetration in sediments (Mayer et al. 1995), none of the sediment cores collected at the farm site contained these organisms. SFM simulations revealed that the aerobic layer depth was substantially reduced as POM loading to sediments and sediment $\mathrm{O}_{2}$ uptake increased (both spatially and temporally), but these declines in aerobic layer depth were not substantial enough to severely limit nitrification (Fig. 10) and sediment-water $\mathrm{NO}_{3}{ }^{-}$fluxes were relatively small across all sites. Although denitrification was reduced at the farm and reference sites in August when aerobic layer depth was at its seasonal minimum, even the model simulations forced with the largest POM deposition rates did not substantially alter computed denitrification rates. Denitrification rates likely remained high because overlying water $\mathrm{O}_{2}$ concentrations were always relatively high ( $>94 \mu \mathrm{M}$ observed at the farm site over a $3 \mathrm{wk}$ period in August 2011) in the simulations, allowing for the persistence of an aerobic layer and nitrification despite high POM deposition. If sediment oxygen uptake was as high as predicted under the highest POM deposition scenarios $\left(200 \mathrm{mmol} \mathrm{O}_{2} \mathrm{~m}^{-2} \mathrm{~d}^{-1}\right)$, the $\mathrm{O}_{2}$ stock in a $0.5 \mathrm{~m}$ water column (assuming $187 \mu \mathrm{M} \mathrm{O}_{2}$ ) would be depleted in $11 \mathrm{~h}$ (also assuming minimal air-sea exchange). Assuming that maximum POM deposition is possible under very quiescent periods, these results suggest that the overlying water could have become hypoxic during dark hours at the farm and severely diminish the aerobic layer, limiting denitrification (Testa \& Kemp 2012); however, the present study is lacking in these observations.

Microphytobenthic production may also influence nutrient and oxygen cycling at the sites we visited in 
this study. Although this site is extremely shallow, the water column is highly turbid $\left(k_{\mathrm{d}}=0.7-3.9\right.$ from April to September), limiting the amount of light that can reach the bottom. Measurements of surface and bottom PAR indicate that the sediments at the farm site received between 12.5 and $148 \mu \mathrm{E} \mathrm{m} \mathrm{m}^{-2} \mathrm{~s}^{-1}$ during April to September (roughly 1-45\% of surface light) and $<25 \%$ of surface light in June to August. This amount of light could support microphytobenthic algal production at the sediment surface, where sediment cores that were incubated in $225 \mu \mathrm{E} \mathrm{m}{ }^{-2} \mathrm{~s}^{-1}$ of light for 3-4 h showed 15-200\% declines in sediment $\mathrm{O}_{2}$ uptake and 21-106\% declines in sediment $\mathrm{NH}_{4}{ }^{+}$ release, yet variable impacts on $\mathrm{N}_{2}$, and $\mathrm{NO}_{3}{ }^{-}$fluxes (data not shown). Thus, the sediments at the farm study site may release less $\mathrm{N}$ and consume less $\mathrm{O}_{2}$ during periods where light reaches the bottom and if significant benthic algal growth occurred. Given that we simulated microphytobenthic growth, the SFM deposition rate would likely underestimate the true POM deposition, given that less of the $\mathrm{N}$ processed in the sediment would be realized as $\mathrm{NH}_{4}{ }^{+}$if benthic algal $\mathrm{N}$ uptake occurred. Given the high rates of resuspension and biodeposit sinking at the farm site, it is unlikely that significant benthic algal production occurred. In addition, the measured denitrification rates $\left(9-115 \mu \mathrm{mol} \mathrm{N} \mathrm{m}^{-2} \mathrm{~h}^{-1}\right.$ ) were somewhat high for Chesapeake Bay given the observed $\mathrm{NO}_{2}^{-}$plus $\mathrm{NO}_{3}{ }^{-}$concentrations in the overlying water $(1-11 \mu \mathrm{M})$, and if benthic algal photosynthesis was high, it would likely out-compete nitrifying bacteria for $\mathrm{NH}_{4}{ }^{+}$ and thus suppress coupled nitrification-denitrification (Risgaard-Petersen 2003).

$\mathrm{PO}_{4}{ }^{3-}$ fluxes were also similar across all study sites and averages over April to September approached zero at all sites. On the one hand, this should be expected given a well-oxygenated water-column and persistent aerobic layer, which would support a highsorption capacity for $\mathrm{PO}_{4}{ }^{3-}$ given abundant oxidized iron and manganese (Sundby et al. 1986). On the other hand, particulate organic phosphorus deposition was 4 times higher at the farm than at the reference site and therefore, some increases in $\mathrm{PO}_{4}{ }^{3-}$ were expected. Therefore, sediments at all sites appear to retain substantial amounts of Fe-bound $\mathrm{PO}_{4}{ }^{3-}$. Our initial simulations used solid-solute partitioning coefficients that are characteristic of conditions for Chesapeake Bay (Testa et al. 2013), and these simulations predicted modest $\mathrm{PO}_{4}{ }^{3-}$ efflux from sediments, while observations suggested zero flux or net influx. These discrepancies were particularly apparent at the farm site (Fig. 9). The fact that modeled $\mathrm{PO}_{4}{ }^{3-}$ fluxes better agreed with observations upon an increase in these partitioning coefficients (see 'Materials and methods') suggests that these sites (especially the farm) may have a higher effective sorption capacity than adjacent sediments. One explanation for this pattern may be that oysters, in filtering large amounts of water containing high suspended solids, effectively concentrate large amounts of inorganic material in the sediments below the site (sediment trap material was only $2 \%$ carbon). Thus, oysters appeared to be concentrating Fe-rich material and enhancing sorption locally, a finding consistent with oyster biodeposit studies on other Choptank River sediments (Holyoke 2008) suggesting that oysters may engineer their local environment. Many oyster culture operations result in the accumulation of shell material in sediments underlying the site (Langan et al. 2006), but we did not observe much shell in the sediments at the farm site. It is possible that an abundance of calcium carbonate could also enhance the sorption of phosphate or the precipitation of calcium-phosphate minerals (Millero et al. 2001). Although the exact mechanisms may be unknown, oyster-induced biogeochemical changes occurring within aquaculture sites may need to be incorporated into sediment biogeochemical models to adequately capture the dynamics of phosphorus and other elements.

The ability to derive realistic deposition magnitudes using a sediment flux model is a novel tool that should help aquaculturists understand both the physics of depositional transport and the potential biogeochemical perturbation of a site by aquaculture operations. Combining sediment trap deployments (to estimate both biodeposit deposition and resuspension) and model simulations (to estimate incorporation of biodeposits into sediments) provided a fairly comprehensive view of particle transport at the farm. Given a modest field program to measure watercolumn nutrient and oxygen concentrations and a few sediment-water $\mathrm{NH}_{4}{ }^{+}$flux rates, SFM could be used as a management and site-selection tool to predict the potential for adverse effects from shellfish farming. Additional benefits to this approach are the ability to simulate sediment oxygen uptake and denitrification reasonably well with minimal calibration. Residuals between observed and modeled $\mathrm{PO}_{4}{ }^{3-}$ fluxes suggest a yet unincorporated sediment phosphorus process may be at work at aquaculture sites, including interactions between biodeposition, iron, manganese, and sulfur cycling (Holyoke 2008). In order to improve this tool, we recommend further studies that examine phosphorus sorption potential at shellfish aquaculture farms, the impact of short-term oxygen excursions on nutrient cycling, and the incorporation 
of coupled sediment-water column models into aquaculture site selection tools. For this latter tool, feedbacks associated with sediment nutrient-release, primary production, oyster growth, and subsequent biodeposition could be examined.

Acknowledgments. We thank Kevin McClarren and Bob Maze for the opportunity to conduct experiments and field sampling at Marinetics Inc. farm at Castle Haven on the Choptank River, Maryland, USA. Sarah Kwon, Abbas Haghshenas, Randy Neilson, and John Richardson contributed to the analysis. We also thank the United States Environmental Protection Agency Chesapeake Bay Program and the Maryland Department of Natural Resources for collecting some of the water chemistry data used in this analysis. Funding for this work came from the NOAA Sea Grant Aquaculture Research Program (NA10OAR4170072): Predicting spatial impacts of bivalve aquaculture on nutrient cycling and benthic habitat quality (2010-2013). This work is the University of Maryland Center for Environmental Science Publication no. 5087. This activity was also supported by the National Science Foundation award no. IIA-1355457 to Maine EPSCoR at the University of Maine.

\section{LITERATURE CITED}

Asmus RM, Asmus H (1991) Mussel beds: limiting or promoting phytoplankton? J Exp Mar Biol Ecol 148:215-232

> Barranguet C (1997) The role of microphytobenthic primary production in a Mediterranean mussel culture area. Estuar Coast Shelf Sci 44:753-765

Bayne BL Newell RC (1983) Physiological energetics of marine molluscs. In: Saleuddin ASM, Wilbur KM (eds) The Mollusca, Vol 4, Physiology, Part I. Academic Press, New York, NY

> Bertics VJ, Löscher CR, Salonen I, Dale AW, Gier J, Schmitz RA, Treude T (2013) Occurrence of benthic microbial nitrogen fixation coupled to sulfate reduction in the seasonally hypoxic Eckernförde Bay, Baltic Sea. Biogeosciences 10:1243-1258

Brady DC, Testa JM, Di Toro DM, Boynton WR, Kemp WM (2013) Sediment flux modeling: calibration and application for coastal systems. Estuar Coast Shelf Sci 117: 107-124

Burdige DJ (1991) The kinetics of organic matter mineralization in anoxic marine sediments. J Mar Res 49:727-761

Byron C, Link J, Costa-Pierce B, Bensgton D (2011) Calculating ecological carrying capacity of shellfish aquaculture using mass-balance modeling: Narragansett Bay, Rhode Island. Ecol Modell 222:1743-1755

> Cai WJ, Sayles FL (1996) Oxygen penetration depths and fluxes in marine sediments. Mar Chem 52:123-131

Cornwell JC, Glibert PM, Owens MS (2014) Nutrient fluxes from sediments in the San Francisco Bay Delta. Estuaries Coasts 37:1120-1133

> Cranford PJ, Hargrave BT, Doucette LI (2009) Benthic organic enrichment from suspended mussel (Mytilus edulis) culture in Prince Edward Island, Canada. Aquaculture 292:189-196

Cranford PJ, Evans DA, Shumway SE (2011) Bivalve filter feeding: variability and limits of the aquaculture biofilter. In: Shumway SE (ed) Shellfish Aquaculture and the Environment. Wiley, Oxford

Crawford CM, Macleod CK, Mitchell IM (2003) Effects of shellfish farming on the benthic environment. Aquaculture 224:117-140

Di Toro DM (2001) Sediment flux modeling, Vol 116. WileyInterscience, New York, NY

Duarte P, Meneses R, Hawkins AJS, Zhu M, Fang J, Grant J (2003) Mathematical modelling to assess the carrying capacity for multi-species culture within coastal waters. Ecol Modell 168:109-143

> Dudley RW, Panchang VG, Newell CR (2000) Application of a comprehensive modeling strategy for the management of net-pen aquaculture waste transport. Aquaculture 187: 319-349

> Dumbauld BR, Ruesink JL, Rumrill SS (2009) The ecological role of bivalve shellfish aquaculture in the estuarine environment: a review with application to oyster and clam culture in West Coast (USA) estuaries. Aquaculture 290:196-223

$>$ Fennel K, Brady D, DiToro D, Fulweiler RW and others (2009) Modeling denitrification in aquatic sediments. Biogeochemistry 93:159-178

Forrest BM, Keeley NB, Hopkins GA, Webb SC, Clement DM (2009) Bivalve aquaculture in estuaries: review and synthesis of oyster cultivation effects. Aquaculture 298: $1-15$

- Gangnery A, Bacher C, Buestel D (2001) Assessing the production and the impact of cultivated oysters in the Thau lagoon (Mediterranee, France) with a population dynamics model. Can J Fish Aquat Sci 58:1012-1020

> Gao Y, Cornwell JC, Stoecker DK, Owens MS (2014) Influence of cyanobacterial blooms on sediment biogeochemistry and nutrient fluxes. Limnol Oceanogr 59:959-971

Giles H, Pilditch CA, Bell DG (2006) Sedimentation from mussel (Perna canaliculus) culture in the Firth of Thames, New Zealand: impacts on sediment oxygen and nutrient fluxes. Aquaculture 261:125-140

> Grant J, Cranford P, Hargrave B, Carreau M and others (2005) A model of aquaculture biodeposition for multiple estuaries and field validation at blue mussel (Mytilus edulis) culture sites in eastern Canada. Can J Fish Aquat Sci 62:1271-1285

Grote A (1934) Der Sauerstoffhaushalt der Seen. Die Binnengewässer, Vol 14. Schweizerbart, Stuttgart

$>$ Hagy JD, Boynton WR, Jasinski DA (2005) Modeling phytoplankton deposition to Chesapeake Bay sediments during winter-spring: interannual variability in relation to river flow. Estuar Coast Shelf Sci 62:25-40

Henriksen K, Kemp WM (1988) Nitrification in estuarine and coastal marine sediments. In: Blackburn TH, Sørensen J (eds) Nitrogen cycling in coastal marine environments. JohnWiley \& Sons, New York, NY

Higgins CB, Tobias C, Piehler MF, Smyth AR, Dame RF, Stephenson K, Brown BL (2013) Effect of aquacultured oyster biodeposition on sediment $\mathrm{N}_{2}$ production in Chesapeake Bay. Mar Ecol Prog Ser 473:7-27

Holyoke RR (2008) Biodeposition and biogeochemical processes in shallow, mesohaline sediments of Chesapeake Bay. $\mathrm{PhD}$ dissertation, University of Maryland, College Park, MD

> Hooke R, Jeeves TA (1961) 'Direct search' solution of numerical and statistical problems. J Assoc Comp Mach 8:212-229

Hutchinson G (1957) A treatise on limnology, Vol 1. Chemistry in Lakes. John Wiley \& Sons, New York, NY

Jorgensen BB, Revsbech NP (1985) Diffusive boundary layers and the oxygen uptake of sediments and detritus. Limnol Oceanogr 30:111-122

Kana TM, Darkangelo C, Hunt C, Oldham J, Bennett G, 
Cornwell J (1994) A membrane inlet mass spectrometer for rapid high precision determination of $\mathrm{N}_{2}, \mathrm{O}_{2}$, and $\mathrm{Ar}$ in environmental water samples. Anal Chem 66:4166-4170

Kaspar HF, Gillespie PA, Boyer IC, MacKenzie AL (1985) Effects of mussel aquaculture on the nitrogen cycle and benthic communities in Kenepuru Sound, Marlborough Sounds, New Zealand. Mar Biol 85:127-136

Kellogg ML, Cornwell JC, Owens MS, Paynter KT (2013) Denitrification and nutrient assimilation on a restored oyster reef. Mar Ecol Prog Ser 480:1-19

Kemp WM, Sampou P, Caffrey J, Mayer M, Henriksen K, Boynton WR (1990) Ammonium recycling versus denitrification in Chesapeake Bay sediments. Limnol Oceanogr 35:1545-1563

Kemp WM, Puskaric S, Faganeli J, Smith EM, Boynton WR (1999) Pelagic-benthic coupling and nutrient cycling. In: Malone TC, Malej A, Harding Jr LW, Smodlaka N, Turner RE (eds) Coastal and estuarine studies, ecosystems at the land-sea margin: drainage basin to coastal sea. American Geophysical Union, Washington, DC

Ko FC, Sanford LP, Baker JE (2003) Internal recycling of particle reactive organic chemicals in the Chesapeake Bay water column. Mar Chem 81:163-176

Langan R, Newell RIE, McVey JP, Newell C, Soles JE, Rensel JEJ, Yarish C (2006) The USA Management Scenario. In: McVey JP, Lee CS, O'Bryen PJ (eds) Aquaculture and ecosystems: an integrated coastal and ocean management approach. World Aquaculture Society, Baton Rouge, LA

Mallet AL, Carver CE, Landry T (2006) Impact of suspended and off-bottom Eastern oyster culture on the benthic environment in eastern Canada. Aquaculture 255:362-373

Mayer MS, Shaffner L, Kemp WM (1995) Nitrification potentials of benthic macrofaunal tubes and burrow walls: effects of sediment $\mathrm{NH}_{4}{ }^{+}$and animal irrigation behavior. Mar Ecol Prog Ser 121:157-169

Mazouni N (2004) Influence of suspended oyster cultures on nitrogen regeneration in a coastal lagoon (Thau, France). Mar Ecol Prog Ser 276:103-113

Mazouni N, Gaertner JC, Deslous-Paoli JM, Landrein S, Geringer d'Oedenberg M (1996) Nutrient and oxygen exchanges at the water-sediment interface in a shellfish farming lagoon (Thau, France). J Exp Mar Biol Ecol 205: 91-113

McKindsey CW, Archambault P, Callier MD, Olivier F (2011) Influence of suspended and off-bottom mussel culture on the sea bottom and benthic habitats: a review. Can J Zool 89:622-646

Millero F, Huang F, Zhu X, Liu X, Zhang JZ (2001) Adsorption and desorption of phosphate on calcite and aragonite in seawater. Aquat Geochem 7:33-56

Mitchell IM (2006) In situ biodeposition rates of Pacific oysters (Crassostrea gigas) on a marine farm in Southern Tasmania (Australia). Aquaculture 257:194-203

Murray TJ, Hudson K (2013) Economic activity associated with shellfish aquaculture in Virginia, 2012. Marine Resource Report No. 2013-4. Virginia Institute of Marine Science, Glouchester Point, VA

NASS (2014) Census of aquaculture (2013). National Agricultural Statistic Service, United States Department of Agriculture. www.agcensus.usda.gov/Publications/ Census_of_Aquaculture/ (accessed 10 September 2014)

Editorial responsibility: Philippe Archambault,

Rimouski, Québec, Canada
Newell RIE (2004) Ecosystem influences of natural and cultivated populations of suspension-feeding bivalve molluscs: a review. J Shellfish Res 23:51-62

Newell RIE, Langdon CJ (1996) Mechanisms and physiology of larval and adult feeding (Chapter 5). In: Kennedy VS, Newell RIE, Eble A (eds) The eastern oyster, Crassostrea virginica. Maryland Sea Grant, College Park, MD

NRC (National Research Council) (2010) Ecosystem concepts for sustainable bivalve mariculture. National Academies Press, Washington, DC

Ren JS, Stenton-Dozey J, Plew DR, Fang J, Gall M (2012) An ecosystem model for optimising production in integrated multitrophic aquaculture systems. Ecol Modell 246:34-46

Rich JJ, Dale OR, Song B, Ward BB (2008) Anaerobic ammonium oxidation (anammox) in Chesapeake Bay sediments. Microb Ecol 55:311-320

Risgaard-Petersen N (2003) Coupled nitrification-denitrification in autotrophic and heterotrophic estuarine sediments: on the influence of benthic microalgae. Limnol Oceanogr 48:93-105

Roden EE, Tuttle JH, Boynton WR, Kemp WM (1995) Carbon cycling in mesohaline Chesapeake Bay sediments 1: POC deposition rates and mineralization pathways. J Mar Res 53:799-819

- Rysgaard S, Risgaard-Petersen N, Sloth NP, Jensen K, Nielsen LP (1994) Oxygen regulation of nitrification and denitrification in sediments. Limnol Oceanogr 39: 1643-1652

Seitzinger SP (1988) Denitrification in freshwater and coastal marine ecosystems: ecological and geochemical significance. Limnol Oceanogr 33:702-724

Souchu P, Vaquer A, Collos Y, Landrein S, Deslous-Paoli JM, Bibent B (2001) Influence of shellfish farming activities on the biogeochemical composition of the water column in Thau lagoon. Mar Ecol Prog Ser 218:141-152

> Sundby B, Anderson LG, Hall POJ, Iverfeldt A, Rutgers van der Loeff MM, Westerlund SFG (1986) The effect of oxygen on release and uptake of cobalt, manganese, iron and phosphate at the sediment-water interface. Geochim Cosmochim Acta 50:1281-1288

Tenore KR, Boyer LF, Cal RM, Corral J and others (1982) Coastal upwelling in the Rias Bajas, NW Spain: contrasting the benthic regimes of the Rias de Arosa and de Muros. J Mar Res 40: 701-772

Testa JM, Kemp WM (2012) Hypoxia-induced shifts in nitrogen and phosphorus cycling in Chesapeake Bay. Limnol Oceanogr 57:835-850

Testa JM, Brady DC, Di Toro DM, Boynton WR, Cornwell JC, Kemp WM (2013) Sediment flux modeling: nitrogen, phosphorus and silica cycles. Estuar Coast Shelf Sci 131: 245-263

- Ward JE, Shumway SE (2004) Separating the grain from the chaff: particle selection in suspension- and deposit-feeding bivalves. J Exp Mar Biol Ecol 300:83-130

Weise AM, Cromey C, Callier MD, Archambault P, Chamberlain J, McKindsey CW (2009) Shellfish-DEPOMOD: Modelling the biodeposition from suspended shellfish aquaculture and assessing benthic effects. Aquaculture 288:239-253

Westrich JT, Berner RA (1984) The role of sedimentary organic matter in bacterial sulfate reduction: the $G$ model tested. Limnol Oceanogr 29:236-249

Submitted: December 19, 2014; Accepted: September 1, 2015 Proofs received from author(s): October 13, 2015 